\title{
Grain legume decline and potential recovery in European agriculture: a review
}

\author{
Peter Zander $^{1}$ - T. S. Amjath-Babu ${ }^{1}$ - Sara Preissel ${ }^{1}$ - Moritz Reckling ${ }^{2,3}$. \\ Andrea Bues $^{1,4}$ • Nicole Schläfke ${ }^{1}$ • Tom Kuhlman ${ }^{5}$ - Johann Bachinger ${ }^{2}$. \\ Sandra Uthes ${ }^{1}$ - Fred Stoddard ${ }^{6}$ - Donal Murphy-Bokern ${ }^{7}$. Christine Watson ${ }^{3,8}$
}

Accepted: 23 March 2016 / Published online: 19 April 2016

(C) INRA and Springer-Verlag France 2016

\begin{abstract}
Sustainable development of agriculture is at the core of agricultural policy debates in Europe. There is a consensus that diversification of cropping would support sustainable development. However, a reduction in legume cultivation has been observed in the EU during the last decades. This decline has induced, in turn, a deficit of proteins and a
\end{abstract}

T. S. Amjath-Babu

amjath.babu@zalf.de

Peter Zander

Peter.Zander@zalf.de

Sara Preissel

Sara.Preissel@zalf.de

Moritz Reckling

Moritz.Reckling@zalf.de

Andrea Bues

Bues@irs-net.de

Nicole Schläfke

Nicole.Schlaefke@zalf.de

Tom Kuhlman

tom.kuhlman@kpnmail.nl

Johann Bachinger

JBachinger@zalf.de

Sandra Uthes

Uthes@zalf.de

Fred Stoddard

Frederick.Stoddard@helsinki.fi reduction of ecosystem services provided by legumes. Therefore, we analysed the mechanisms that shape agricultural systems to identify leverage points for reviving European legume production. Specifically, we reviewed the factors that affect the market and non-market value of legumes and the relevant agricultural policies. We characterized the decline in

Donal Murphy-Bokern

Donal@Murphy-Bokern.com

Christine Watson

Christine.Watson@sruc.ac.uk

1 Institute of Socio-Economics, Leibniz Centre for Agricultural Landscape Research (ZALF), Eberswalder Strasse 84, 15374 Muencheberg, Germany

2 Institute of Land Use Systems, Leibniz Centre for Agricultural Landscape Research (ZALF), Eberswalder Strasse 84, 15374 Muencheberg, Germany

3 Department of Crop Production Ecology, Swedish University of Agricultural Sciences (SLU), Box 7043, 75007 Uppsala, Sweden

4 Leibniz Institute for Regional Development and Structural Planning (IRS), Erkner, Germany

5 Agricultural Economics Research Institute (LEI), Wageningen UR, Alexanderveld 5, 2585 DB Den Haag, The Netherlands

6 Department of Agricultural Sciences, University of Helsinki, PL 27 (Latokartanonkaari 5), Helsinki, Finland

7 Murphy-Bokern Konzepte, Lindenweg 12, 49393 Lohne-Ehrendorf, Germany

8 Crop and Soil Systems, Scotland's Rural College (SRUC), Craibstone Estate, Aberdeen AB21 9YA, UK 
legume cropping as an outcome of the dominance of economic forces that favour specialization of production systems over diversification. We found that the value of market outputs of legumes per unit area is relatively low and volatile, with a 25 $78 \%$ variation in pea gross margins, which reduces market competitiveness. We observed that the value of systeminternal outputs of legumes such as the nitrogen fixed, of 130 to $153 \mathrm{~kg} \mathrm{~N} \mathrm{ha}^{-1}$; crop protection services that reduce agrochemical costs, by $20-25 \%$ in cereals; and yield enhancements of subsequent crops, of 0.2 to $1.6 \mathrm{t} \mathrm{ha}^{-1}$ in cereals, are often underestimated. In addition, markets fail to translate external effects of legumes such as biodiversity enhancement, reduction in emissions, of up to $50 \%$ in $\mathrm{N}_{2} \mathrm{O}$, and soil improvements into economic benefits. Current policies support legumes through selected mechanisms such as ecological focus areas, agri-environmental programmes and sparse coupled support measures. Domestic cultivation of legumes could be supported through trade policies such as import restrictions on genetically modified soybean or new mechanisms to appreciate non-market outputs including payments for ecosystem services and carbon markets. In addition, development of new value chains, niche markets, scaling-up of plant breeding efforts and dissemination of information is required.

Keywords Land use change · Protein crops - Diversification . Specialization · Economic pressures $\cdot$ Sustainable land use

\section{Contents}

1. Introduction

2. Development and current situation of grain legume cultivation in Europe

3. Factors affecting marketed outputs

3.1 Volatility of grain yields and revenues

3.2 Market conditions

3.2.1 Human consumption of legumes

3.2.2 Dietary change

3.2.3 Health impact of legumes

3.2.4 Grain legumes in feed

3.3 Relative gross margin of legumes

4 Factors affecting internal non-market outputs

4.1 Nitrogen fixation

4.2 Savings from pest control services

4.3 Yield enhancement of subsequent crops

5 Factors affecting external impacts of legumes

5.1 Biodiversity enhancement

5.2 Emission reduction in crop production

5.2.1 Nitrate leaching

5.2.2 Gaseous emissions

5.3 Soil improvement

5.4 Phosphorus mobilization
5.5 Emission reductions from animal production

6 Impact of subsidies and other policies in the European Union

6.1 History of direct subsidies for legumes

6.2 Subsidies to competing crops

6.3 Coupled support in the current and reformed Common Agricultural Policy

6.4 Greening under the reformed Common Agricultural Policy

6.5 Support to sustainable farming practices

6.6 Support outside the Common Agricultural Policy

7 Outlook

7.1 Improving marketed outputs

7.2 Support for non-market outputs

7.2.1 Awareness among producers

7.2.2 Policy

8 Conclusions

9 References

\section{Introduction}

The sustainable development of agriculture is at the core of agricultural policy debates in Europe, and there is a consensus that diversification of agriculture is needed to achieve this goal (Davis et al. 2012; Lin 2011). In contrast, one of the larger shifts in production patterns i.e. substantial reduction in legume cultivation in Europe caused a significant decline in crop diversity in the EU during the last decades. This decline resulted in foregone ecosystem service provision and a production deficit of plant proteins in Europe. So, it is imperative to discuss the reasons for the decline in grain legume cultivation and ways to reverse this trend. We take the view that imbalances between two basic and opposing transition pressures (Amjath-Babu and Kaechele 2015) are behind the decline in legume production in Europe. One pressure is the economic effect of specialization (crops here) that is grounded in David Ricardo's 'law' of comparative advantage that drives much of international trade and economic development and growth (Gale 2000). Economy of scale is one of the key sources of comparative advantage and hence the specialization trend in farming. The other is the ecological benefits of crop diversification including nutrient provision, emission reduction, biodiversity enhancement, pest and disease management (Kremen and Miles 2012) and its translation to economic benefits. The current study attempts to identify the leverage points for restoring grain legume production through an in-depth analysis of the transition pressures. 
There is a general trend towards simplification and specialization of agricultural production systems over time, in Europe and elsewhere (Brouwer 2006). This results in a gradual reduction in diversity with homogenisation of farm landscapes caused by a deliberate reduction in planned diversity with cropping sequences (crop rotations). Associated with this, there is usually degradation of biological functions, for example, ecological pest management replaced by pesticide use or biological nitrogen fixation (BNF) replaced by mineral fertilizers (Noordwijk and Swift 1999). Grain legumes are a group of crops that is an important component of diversified farming systems. They provide services such as pest control, nutrient supply and biodiversitybased insurance (Baumgärnter 2007). The ecosystem service effects of these diversified farming systems are often not well recognized and are therefore undervalued. This is due, at least in part, to their complexity in both ecological and management terms, particularly in relation to variability in soils, weather and the interaction of these factors with management (Pannell 1999). In relation to forestry, Gale (2000) concluded that it is necessary to find compromises between specialization and diversification forces to secure and develop sustainable production systems. This may need public support for the management of agroecosystems to reduce negative external effects. In other words, negative external effects that are caused by market failures should be addressed by regulations that internalize externalities using payment for ecosystem services or that penalize dis-services. This can be agrienvironmental regulations, public payments or private payments.

From a socio-technical viewpoint, Voisin et al. (2014) reviewed the development and current situation of legume production in France and concluded that a 'technological lock-in' exists: While legume cultivation is highly efficient in the use of internally produced (fixed) nitrogen, the whole socio-technical system of farming relies on the use of external resources, especially feed and fertilizers, and is difficult to change. They propose developments of niches and wider policy support for a transition to more diverse agricultural systems. Complementing their assessment, the mechanisms and pressures that shape agricultural systems are analysed in-depth to identify leverage points for reviving European legume production. Ultimately, farmers decide which pathway they follow, towards further specialization of agroecosystems serving to existing markets or towards realizing the benefits from diversified production systems through entrepreneurship and innovative technologies.

Figure 1 shows the major factors within the decision framework of farmers that affect the net economic benefits from specialization and diversification options. We argue that there are a number of farm-level benefits of legumes that are often not realized or understood by farmers or that could be further developed. General market pressure reinforces large-scale cultivation of the best-performing crops and enforces cost reduction, including management costs. On the other hand, the translation of nonmarket output of diversified agriculture (here legumes) into tangible economic returns is seldom accomplished. Hence, the current setting leads to simplified production systems, and their negative environmental impacts are usually externalized. Under this framework, in addition to enhancing the value of marketed output of legumes, translation of non-market outputs to economic goods through agro-environmental payments, greening rules and in the future possibly greenhouse gas abatement payments from carbon markets could support inclusion of legumes in European farming systems. It is of course imperative that any possible negative impacts of legumes on the environment are also accounted for.

The net economic value of marketed and non-marketed outputs and services realized at farm level is a major factor determining crop choice of European farmers. In case of legumes, any deficit in the economic return from marketed outputs relative to competing crops can lead to their exclusion and hence increase the pressure to specialize into latter crops, whereas any increase in the economic value of non-marketed outputs realized at farm level can increase the incentive to include them in cropping system and hence enhance the pressure to diversify. We use this basic framework to analyse the factors that are ultimately responsible for decisions related to the production of legumes at the farm level in order to improve our understanding of the reasons for the decline of legume cultivation in European farming systems and to evaluate options for improvement.

We portray the decision that a farmer makes to choose legumes as a reflection of the net economic return including marketed and non-marketed products and services from their cultivation in relation to the net economic return from the next best alternative crop. The major factors affecting the relative economic returns from marketed outputs of grain legumes are food and feed market conditions, volatility of returns and gross margins of competing crops (Section 3). The valuation of non-marketed products and services such as BNF, pest control and the yield enhancement of subsequent crops depend on various factors such as the level of pesticide and fertilizer prices, the degree of understanding and appreciation of these effects by farmers and the mechanisms to obtain payments for positive externalities (Section 4).

\section{Development and current situation of grain legume cultivation in Europe}

Until about 1970, common bean (Phaseolus vulgaris L.) was the most widely cultivated grain legume in Europe. Following the introduction of policy support for soybean and protein feed crops in the 1970s, field pea (Fig. 2) and soybean became the most widely grown grain legumes. Peak production areas of these 
Fig. 1 Factors influencing farmer's crop choices

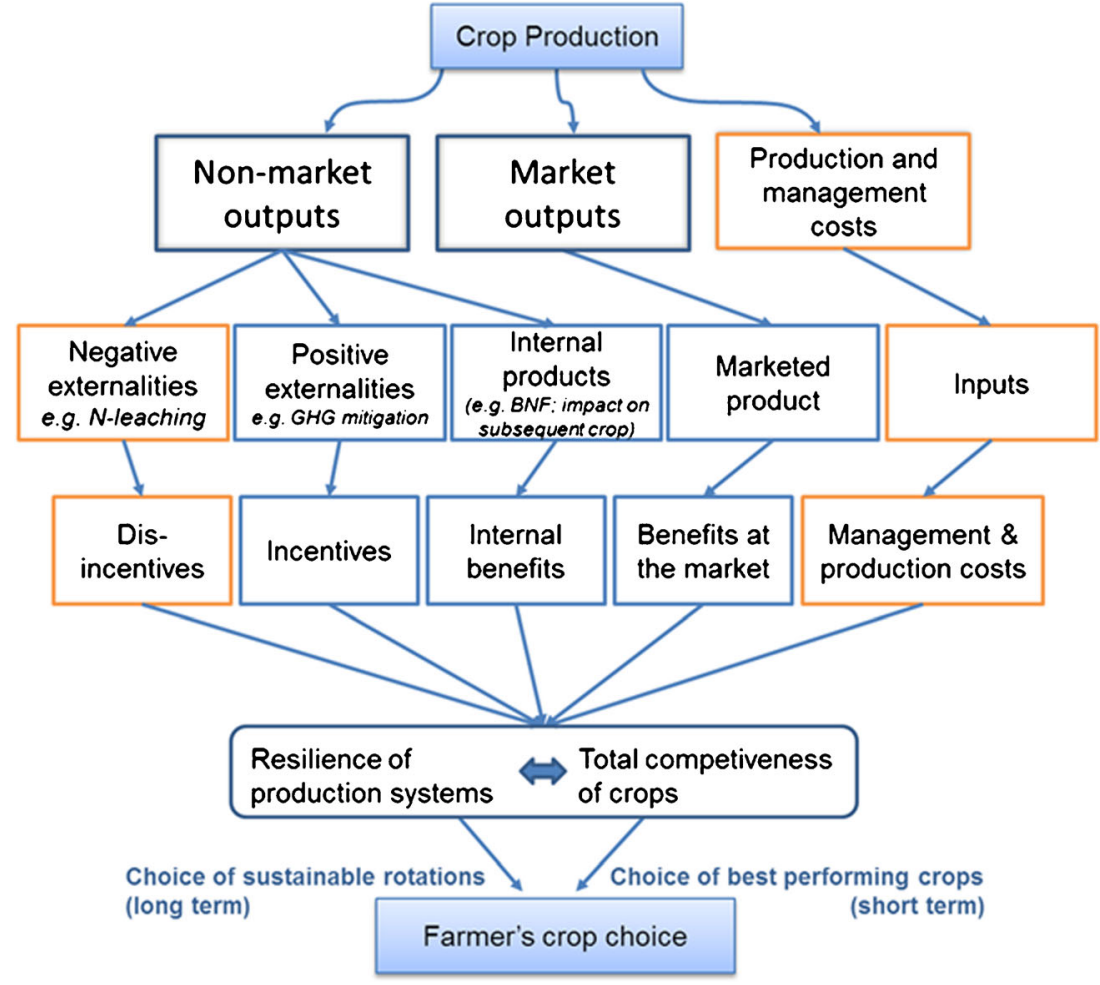

crops exceeded 1.3 and $1 \mathrm{M}$ ha, respectively, but both have declined since the 1990s. In 2013, pea, soybean and faba bean (Fig. 3) covered 200,000 to 500,000 ha each, whereas other grain legumes covered less than 100,000 ha each. Overall, grain legume cultivation declined from 5.8 to $1.8 \mathrm{M}$ ha between 1961 and 2013 (Fig. 4). Despite the decline in area under legumes, the total grain legume production in Europe still increased during that period from 3.3 to $4.2 \mathrm{M} \mathrm{t}$ (FAOstat 2015), but the productivity gains were lower than those observed in major cereals. Rapeseed and sunflower production expanded in terms of the proportion of the arable area while cereals and forage maize retained their share of around $57 \%$.

Grain legumes deliver a unique combination of highprotein grain for food and feed, BNF, improve cropping systems in terms of reduced pests, diseases and weeds, enhance soil quality and support positive environmental impacts such as reduction in greenhouse gas emissions and increased biodiversity (Kirkegaard et al. 2008; Nemecek et al. 2008; Peoples et al. 2009a; Peoples et al. 2009b). Due to the high protein content (23-40\%) in the seed dry matter, they play a key role in protein supply for human consumption and livestock nutrition. Using BNF negates or reduces the need for synthetic nitrogen $(\mathrm{N})$ fertilizers thereby saving the fossil energy resources required for fertilizer manufacture and transport, and indirectly reducing greenhouse gas emissions (Nemecek et al. 2008; Westhoff 2009). Grain legumes increase the yield of subsequent crops in the rotation not only because of BNF but also due to non-nitrogen effects such as pest and disease suppression (Chalk 1998). In addition, the increased crop diversity that results from including legumes in cropping sequences supports the associated diversity of wild flora, fauna, and soil microbes (Peoples et al. 2009b; Köpke and Nemecek 2010).

Currently, $3 \%$ of soy used in Europe is sourced domestically, and domestic and imported soybean together supply $64 \%$ of high-protein crop plant product consumed in Europe (de Visser et al. 2014). Domestically produced soybean accounts for only $3.4 \%$ of the high-protein feed material used (PROLEA 2013). The large-scale import of soybean as a substitute for domestic production of protein crops, especially legumes, is not sustainable for a variety of reasons. The concentration of animal production in certain regions of Europe

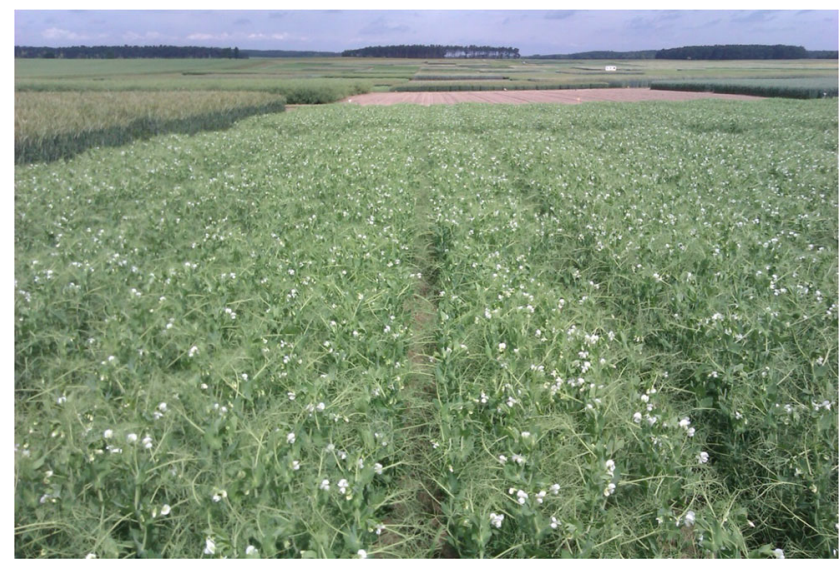

Fig. 2 Variety trials of field pea (Pisum sativum L.) in northeastern Germany 


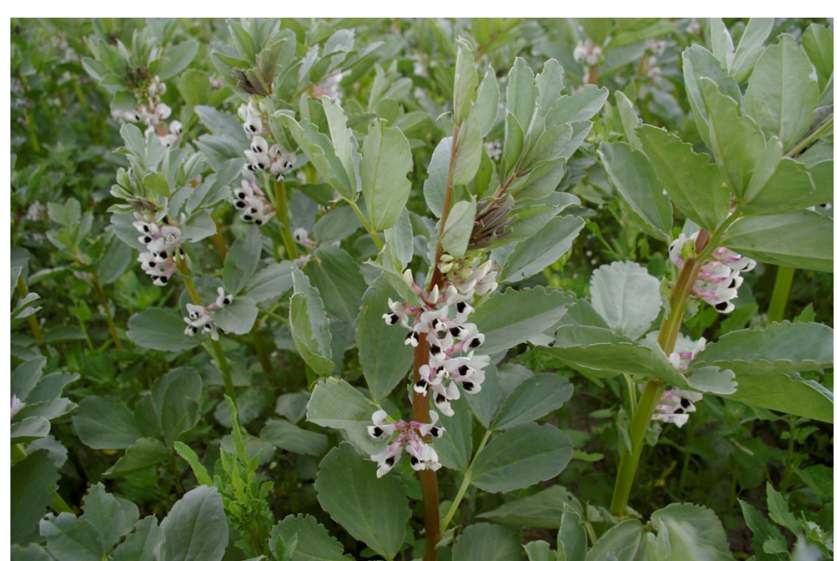

Fig. 3 Faba bean (Vicia faba L.) grown for feed

results in a high per hectare organic manure input (Mulligan et al. 2006) and hinders efficient circulation of nutrients within the agricultural system. It is estimated that the $28 \mathrm{M}$ t soybean meal derived from imports represent approximately $12.8 \mathrm{M}$ ha of land outside Europe (de Visser et al. 2014). According to Smaling et al. (2008), about $33 \%$ of $\mathrm{N}$ in soy is lost in animal waste, transport and non-edible and food waste, of which $50 \%$ could be potentially recycled. An increase in legume cultivation in Europe will help to reduce the European plant protein deficit and could contribute to more environmentally and economically sustainable production patterns.

\section{Factors affecting marketed outputs}

\subsection{Volatility of grain yields and revenues}

There is a larger annual yield fluctuation in grain legumes than in most cereals (Cernay et al. 2015. For a risk-averse farmer, high-yield variability (Jensen et al. 2010; Hauggaard-Nielsen et al. 2008; Ayaz et al. 2004; Wright 2008; Sass 2009; Flores et al. 2012) and the resulting high variability of returns with legumes (Table 1) discourage cultivation. This is supported by a survey of farmers in Belgium, Germany, Spain and Switzerland where yield instability was mentioned as a major constraint to grain legume production (von Richthofen et al. 2006). Agronomic management options to improve yield stability are limited (e.g. Yau and Ryan 2013; Stemann and Luetke-Entrup 2001; Ayaz et al. 2004). However, recent analyses (Schäfer 2013; Döring 2015) argue that yield instability of grain legumes is often overestimated. Calculations based on German national yield data from statistics show that variation in yields of field pea and faba bean was lower than those of rapeseed and rye (Schäfer 2013), despite the fact that grain legumes are often grown on less favourable sites. Another research suggests that the scale of yield analysis may influence the variability, for example, Reckling et al. (2015a) showed for a long-term field experiment that yields of field pea and narrow-leafed lupin fluctuated significantly more than yields of other crops. LMC International (2009a) reported that field pea and faba bean gross margin volatilities were lower or comparable to rapeseed, wheat or barley in four out of five case study regions (Table 1). Given the fact that in some regions, production risks are comparable with competing crops and that legumes and cereals respond differently to weather conditions; grain legumes can also play a role in spreading risk (Mishra and Lence 2005; Peltonen-Sainio and Niemi 2012).

\subsection{Market conditions}

\subsubsection{Human consumption of legumes}

In Europe in the 1960s, grain legume crops used exclusively for human consumption such as common bean, chickpea
Fig. 4 Change in the areas of production of key arable crops in the EU-27 (1961-2011). Data source is FAOstat, 2013 and note that pre-1992 data do not include data on crops grown in former Czechoslovakia, Estonia, Latvia, Lithuania and Slovenia

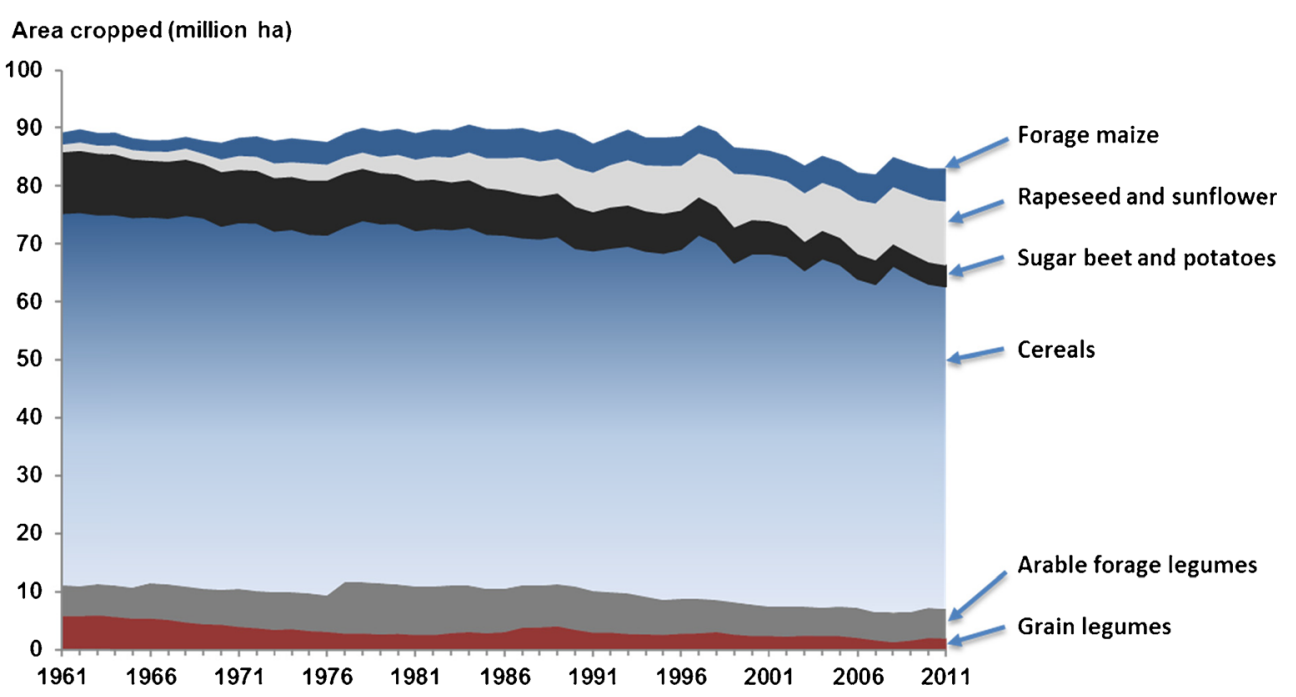


Table 1 Volatility of crop gross margins in 2001-2007

\begin{tabular}{llllll}
\hline & \multicolumn{2}{l}{ Volatility (coefficient of variation \%) } \\
\cline { 2 - 6 } & Faba bean & Pea & Wheat & Barley & Rapeseed/sunflower \\
\hline Germany, Niedersachsen & 46 & 51 & 34 & 21 & 35 \\
Spain, Castilla-La Mancha & - & 78 & 42 & 48 & 74 \\
France, Seine-Maritime & - & 25 & 16 & 18 & 33 \\
France, Eure-et-Loir & - & 31 & 29 & 22 & 22 \\
UK, East Anglia & 36 & 31 & 23 & 21 & 49 \\
\hline
\end{tabular}

Source: LMC International (2009a)
(Cicer arietinum L.), cowpea (Vigna unguiculata L.), groundnut (Arachis hypogaea L.) and lentil (Lens culinaris Medik.) dominated the grain legume cropping. Currently, only $15 \%$ of field pea and $19 \%$ of faba bean consumed in the EU are eaten by humans (PROLEA 2013). However, there may be a substantially higher food market potential considering that the EU is a net importer of the aforementioned grains (2009-2011 data from FAOstat 2015). Within the EU-15,the quantity of pulse-derived protein ranges between 0.1 and $3.7 \mathrm{~g}$ protein per person and day (total protein intake ranging from 96 to $119 \mathrm{~g}$ / person) (de Boer et al. 2006). It is noticeable that the area of grain legumes in the Mediterranean countries (Cyprus, Greece, Italy, Malta, Portugal and Spain) has declined less than in other EU regions over the period 1961-2012. This is partly attributable to the prominent role of food legumes in the regional diet (de Boer et al. 2006).

\subsubsection{Dietary change}

The increase in consumption of animal proteins (Fig. 5) in the EU-15 in the recent past was not associated with reductions in plant protein intake by humans (de Boer et al. 2006). Reducing the current high level of meat consumption has been linked to a potential improvement in health in Europe, as well as reduced demand for soybean for feed with the related environmental impacts and a reduction in the GHG emissions of livestock production. It is estimated that a $50 \%$ reduction in meat and dairy production and consumption could reduce GHG emissions from agriculture by 25 to $40 \%$, and nitrogen emissions by $40 \%$ (Westhoek et al. 2014). Partial meat substitution with soybean proteins in minced and processed meat products has been suggested as a way of reducing livestock production and associated environmental impacts (Smil 2002; Davis et al. 2010). Meat replacement with pulses could contribute to the recommended $62 \%$ reduction in meat consumption in Europe to meet climate goals (Hallström and Börjesson 2012). However, in Europe, a reduction in animal protein consumption would not necessarily require substitution with another protein source as the level of protein intake is high in typical European diets (Westhoek et al. 2014). At the current time, there is little evidence to suggest that European diets are likely to change enough to significantly influence grain legume production.

\subsubsection{Health impact of legumes}

The polyphenols, proteins and phytoestrogens present in grain legumes are associated with various health effects. Increased consumption of grain legumes as well as consumption of targeted functional foods and dietary supplements (or nutraceuticals) based on legumes could help in realizing their positive health effects (Sirtori et al. 2009). Soybean and lupin proteins have the potential to reduce blood cholesterol and thus protect from hypercholesterolemia and atherosclerosis (Harland and Haffner 2008; Marchesi et al. 2008; Sirtori et al. 2012). In addition, lupin proteins are considered to have an antidiabetic effect (Bertoglio et al. 2011). Phytoestrogens from legumes can have potentially positive health effects, for example, reducing the risk of cancer and negative effects on the uterus, thyroid gland and mammary gland (Gierus et al. 2012). Yet, there is a concern about potentially detrimental effects of soybean phytoestrogens as well, e.g. on breast cancer and when used in infant-food formulas (Cederroth \& Nef 2009). Soybean and soybean derivatives are already estimated to be found in about two thirds of all manufactured food products, resulting in an estimated intake of between 0.3 and $1.2 \mathrm{~kg}$ per person per year in the UK (McAusland 2015).

\subsubsection{Grain legumes in feed}

As discussed earlier, the current demand for grain legumes for feed is largely a result of increased meat consumption in the EU (Smil 2002; de Boer et al. 2006; Cavaillès 2009). The prices of European-grown grain legume for animal feed are closely correlated with the world market price of imported soybean (Fig. 6). According to LMC International (2009a), the price of field pea for animal feed is correlated to that of soybean meal and wheat, because feed compounders often replace peas with a mixture of wheat and soybean. Prices have risen sharply since 2007 , and as a result, the cost of the net imports of soybean and soybean cake has doubled compared to the average over the previous 30 years, amounting to $\$ 15.5$ 


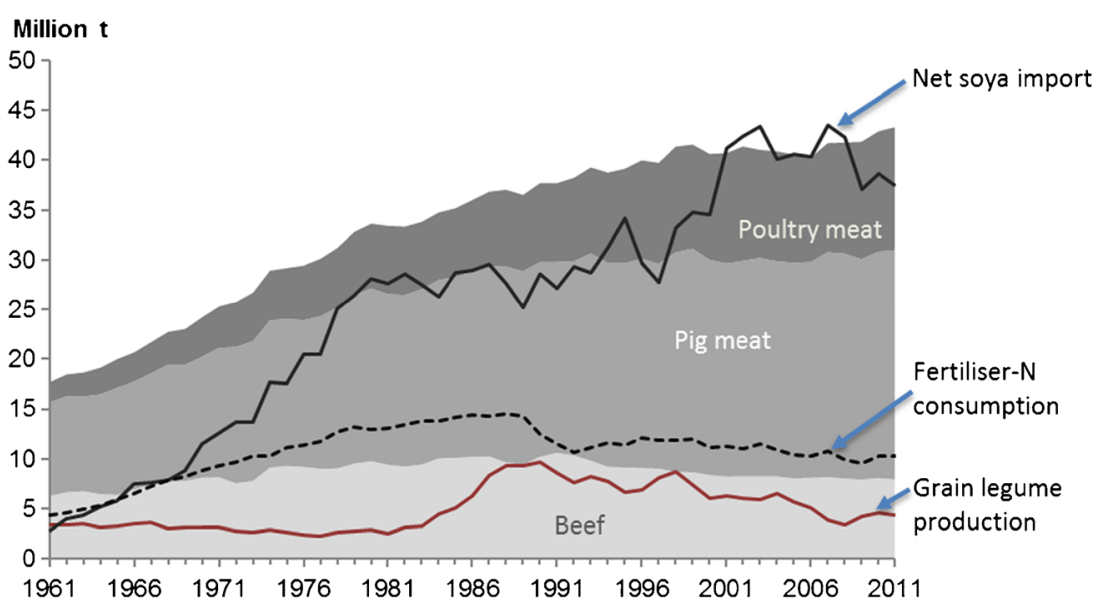

Fig. 5 Changes in the production of meat and corresponding changes in fertilizer $\mathrm{N}$ use, protein crop production and net soybean import (in million tons) for the EU-27 (1961-2011). A more than twofold increase in meat production during this time span raised the (protein) feed demand which was met through a modest increase in domestic production of grain legumes and fertilizer-nitrogen consumption as well as a substantial increase in soya imports. The calculations are based on data from FAOstat (2013)

European-grown legume grain is undervalued in the feed market in relation to its feed value. A mix of domestic legume grains and cereals is often cheaper than an equivalent feed mix of soybean and cereals (Sauermann 2009), and especially so with the recent soybean price increases and a rising demand for GM-free soya from sectors of the market such as organic products (Aramyan et al. 2009).

In order to calculate the 'feed value' of a feed component, we can calculate the amount of that component needed to replace a standard wheat soybean mixture, based on lysine and metabolisable energy (LLH 2012). For given wheat and soybean market prices, faba bean and pea have been undervalued since 2010. In 2014, a gap between market value and the value based on nutritional characteristics was more than $€ 100 \mathrm{t}^{-1}(+55 \%)$ for field pea and $€ 28 \mathrm{t}^{-1}(+10 \%)$
Fig. 6 Changes in producer prices for main protein crops, rapeseed and wheat in major producer countries (1990-2010). The calculations are based on data from FAOstat (2013). Note that prices are averages for major EU producer countries: Bulgaria, France, Poland, Spain and the UK

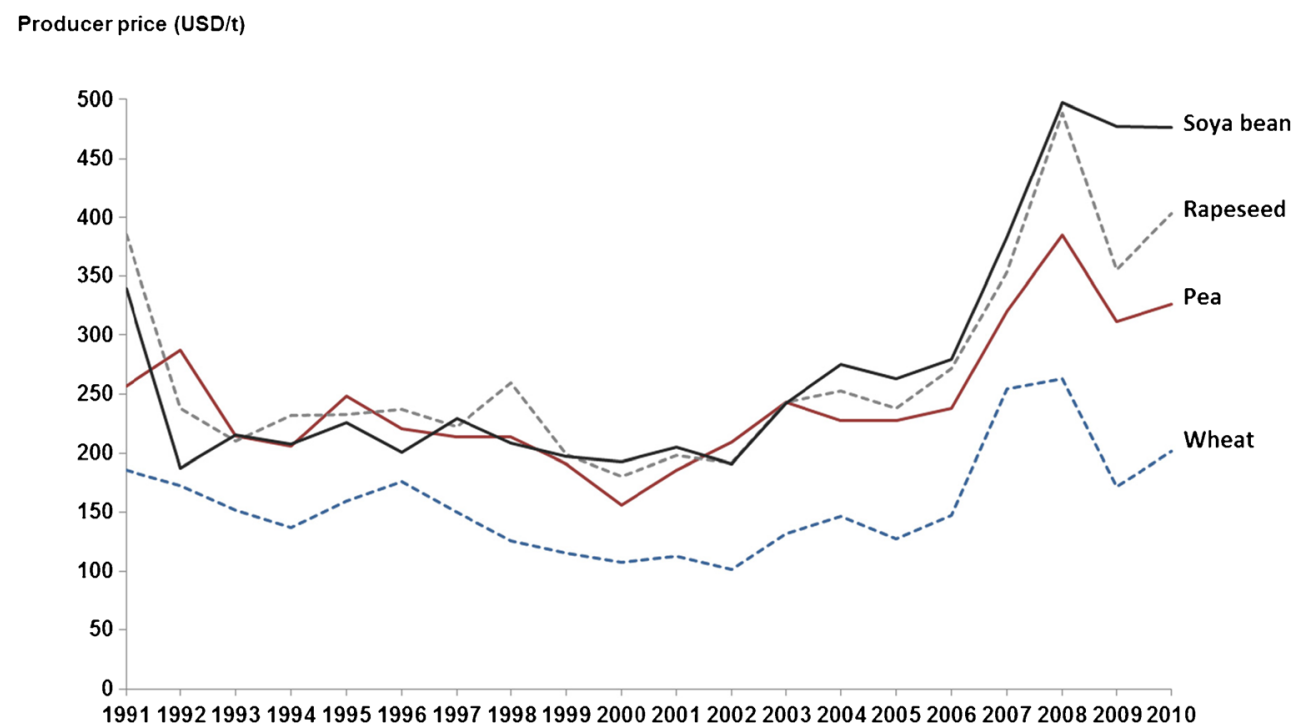


for faba bean. One reason for this gap in price between locally produced grain legume and imported soybean may be that feed compounders prefer larger and more homogenous quantities from large-scale overseas sources (Sauermann 2009; LLH 2012). Closure of the gap could lead to market responses and an increase in European-grown grain legumes for feed production.

\subsection{Relative gross margin of legumes}

The high gross margins from starch-rich cereals are a major driver of simplification and specialization trends. European grain legumes have been shown to have higher gross margin deficits of between 70 and several hundred euros per hectare than other crops in a range of EU countries (Kamp et al. 2010; Mahmood 2011; LMC International 2009b). Grain legumes were competitive with an alternative crop at only four sites (LMC International 2009b; Mahmood 2011; Zilles 2010; Riedesser 2012). However, the gross margins are often compared to the regionally most profitable crop, e.g. wheat, although in reality, competitiveness with a crop of average profitability or with a similar agronomic role in the crop rotation may be sufficient to make farmers decide to grow legumes. Gross margin calculations are not, however, able to take into account the non-market outputs, the long-term economic impacts or possible savings of labour and machinery use associated with grain legumes (Weitbrecht and Pahl 2000).

Preissel et al. (2015) showed that the consideration of precrop effects substantially increases the number of situations where grain legumes can compete with cereals. It also has a small positive effect on their competitiveness compared to alternative break crops. The value of $\mathrm{N}$ fertilization savings (see Section 4.1) due to BNF depends largely on $\mathrm{N}$ fertilizer prices that have doubled since 2000 (EUROSTAT 2015). Westhoff (2009) argues that increasing energy prices directly impact $\mathrm{N}$ fertilizer prices but also might drive up demand for energy crops and thereby world food prices as well. This economic scenario may stabilize the current fertilizer-to-product price ratio and the reliance on manufactured fertilizers instead of BNF. Underestimation of the provision of $\mathrm{N}$ from BNF and low fertilizer-to-product price ratios decrease farmers' interest in intercropping, mixed cropping or crop rotations with legumes.

\section{Factors affecting internal non-market outputs}

As legumes are not always competitive in terms of marketed outputs alone in Europe, economic returns from non-marketed products and services may play an important role in influencing farmers to grow legumes. The larger the economic rewards for non-market goods and services that are available to the farmer, the higher the chance that legume crops are included in farming system.

\subsection{Nitrogen fixation}

From an agro-economic viewpoint, BNF can be regarded as an additional output from the grain legume enterprise, enabling cost savings for (mineral or organic) fertilizer purchases and application. The availability of nitrogen $(\mathrm{N})$ from $\mathrm{BNF}$ reduces the need for $\mathrm{N}$ fertilizers in the legume crop to almost zero. Nitrogen from BNF remaining in above and below ground crop residues after harvest of the grain can be utilized by subsequent crops. Whereas the low $\mathrm{N}$ requirements of legumes are directly reflected in their gross margins, the $\mathrm{N}$ provision to subsequent crops is not usually valued economically. It is not considered in standard gross margin methods and is therefore not used explicitly to inform farmers' decisions made using gross margins. In reality, farmers do not always change their fertilizer application rates in crops following legumes (Preissel et al. 2015), although fertilizer recommendations do take this into account in some countries (see for example Defra 2010).

The most widely grown grain legumes in Europe, field pea and faba bean, accumulate on average 130 and $153 \mathrm{~kg} \mathrm{~N} \mathrm{ha}^{-1}$ in their aboveground biomass through BNF (Peoples et al. 2009b). Large quantities may also be accumulated in belowground biomass associated with nodules and roots representing $30-60 \%$ of the total $\mathrm{N}$ accumulated by legumes (Peoples et al. $2009 b)$. The effects of nitrogen fixation on subsequent crops will depend on the species and amounts of $\mathrm{N}$ fixed as well as environmental conditions. For example, $\mathrm{N}$ uptake in subsequent crops has been reported to be increased by 23-59\% after field pea and narrow-leafed lupin on different soil types in Denmark (Jensen et al. 2004), but only 14-15\% for durum wheat following vetch in a semi-arid Mediterranean environment (Giambalvo et al. 2004). In practice, an actual reduction in $\mathrm{N}$ fertilizer use in subsequent crops will depend on the economic trade-off between securing maximum yields and maximizing $\mathrm{N}$ savings (Preissel et al. 2015). At low $\mathrm{N}$ fertilizer prices relative to product prices, maintaining high yields is more important than fertilizer savings, resulting in minimal fertilizer savings. Surveys among farmers and experts suggest that the reductions in applied fertilizer to crops following legumes are comparable to the potential $\mathrm{N}$ supply of the legume residues, for example, fertilizer savings of between 20 and $30 \mathrm{~kg} \mathrm{ha}^{-1}$ (Alpmann et al. 2013) compared with $18-27 \mathrm{~kg} \mathrm{~N}^{-1}$ residual $\mathrm{N}$ of lupin and pea measured in the subsequent winter barley on a loamy soil (Jensen et al. 2004).

\subsection{Savings from pest control services}

Grain legumes are generally not susceptible to the same pests and diseases as the main cereal crops, and thus, they can break 
the life cycle of these diseases and pests, reducing their incidence and/or severity in the following crop. This is particularly true for soil-borne root diseases such as take-all (Gaeumannomyces graminis) of cereals (Kirkegaard et al. 2008). This break crop effect makes it possible for farmers to reduce pesticide applications in subsequent crops compared to repeated cereal cropping. von Richthofen et al. (2006) found that one fungicide application and one application of selective herbicides against grassweeds could be omitted in cereals grown after legumes with an associated reduction in agrochemical costs of 20-25\% for the succeeding crop and costs savings of up to $31 € \mathrm{ha}^{-1}$. Better recognition of the potential to reduce agrochemical applications and thus expenditure in rotations with grain legumes could make grain legumes more attractive to farmers. However, legumes can also increase the incidence of some diseases, and a 3-4-year interval between successive legume crops is required to control broadspectrum diseases such as Sclerotinia sclerotiorum, Rhizoctonia solani and Aphanomyces (Skuodiene and Nekrosiene 2012).

\subsection{Yield enhancement of subsequent crops}

Introducing grain legumes into cereal-dominated rotations common in much of Europe could lead to a significant increase in cereal yields. In an overview of European experiments, yields of cereals following grain legumes were mostly 0.5 to $1.6 \mathrm{t} \mathrm{ha}^{-1}$ than after cereal pre-crops in temperate conditions, and mostly 0.2 to $1.0 \mathrm{t} \mathrm{ha}^{-1}$ in Mediterranean conditions (Preissel et al. 2015). Yield of crops following legumes is often enhanced due to the combined and interrelated effects of $\mathrm{N}$ provision, pest and disease suppression, improved soil properties and other non-N effects. This positive effect on yield may affect a second or even third crop after the legume (Evans et al. 2003), although this effect is not always found in European experiments (e.g. Charles and Vuilloud 2001; Maidl et al. 1996; Dachler and Köchl 2003). The N-related yield effects are greater in low fertility situations (Preissel et al. 2015). In situations with adequate $\mathrm{N}$ supply, the yield increase to the subsequent crop is mostly from the 'break crop effect' of legumes and other pre-crops such as rapeseed can also produce similar effects. The size of the yield increase varies also with site characteristics and growing conditions (Bachinger and Zander 2007; Kirkegaard et al. 2008). A producer survey in Germany (Alpmann et al. 2013) reported yield increases between 0.5 and $1 \mathrm{t} \mathrm{ha}^{-1}$ when wheat and barley were grown after grain legumes. However, in semi-arid conditions of central Spain, lower yield effects of grain legumes were found, for example, yield increases of $0.2 \mathrm{tha}^{-1}$ for barley following vetch (López-Fando and Almendros 1995). In standard accounting, the increase in yield of the subsequent crop and its economic value are attributed to the following crop and not the grain legume. Consideration of economic and environmental effects at the cropping system level rather than the individual crop level would help farmers improve the valuation of grain legumes as proposed in a recent assessment framework (Reckling et al. 2015b, in press).

\section{Factors affecting external impacts of legumes}

\subsection{Biodiversity enhancement}

Grain legume production increases the diversity of European cropping systems as grain legumes are minor crops throughout Europe and enable temporal and spatial diversification of the agro-ecosystem at the field and landscape level (Peoples et al. 2009b). Increased crop diversity supports increased above and below ground biodiversity (Köpke and Nemecek 2010) including decomposer invertebrates such as earthworms and Collembola (Eisenhauer et al. 2009; Sabais et al. 2011) and pollen- and nectar-gathering wild and domesticated bees as well as bumblebees that are attracted by the crop's mass-flowering habit (Stoddard and Bond 1987; Palmer et al. 2009; Green et al. 1980; Köpke and Nemecek 2010; Westphal et al. 2003). However, benefits of increased diversity of crops and associated diversity are not rewarded in current markets due to institutional failures (Perrings 2001; Pascual and Perrings 2007).

\subsection{Emission reduction in crop production}

\subsubsection{Nitrate leaching}

Emissions of reactive $\mathrm{N}$ to water through nitrate leaching and to the atmosphere through ammonia, nitrous and nitrogen oxide emissions cause nutrient and acid accumulation in vulnerable ecosystems (Galloway et al. 2004). The environmental damage has been estimated to cost $0.31 € \mathrm{~kg}^{-1}$ of $\mathrm{N}$ lost to the environment (von Blottnitz et al. 2006). In arable systems, contribution to nitrate leaching by legumes is conditioned by the crop management, the rotation design and the synchrony of crop $\mathrm{N}$ supply from legumes and the demand from following crops. Nitrate leaching can increase after the grain legume growth cycle as shown for selected cropping systems in Europe (Nemecek et al. 2008). Rotation design, cover crops (Plaza-Bonilla et al. 2015) and intercropping (HauggaardNielsen et al. 2003) are measures to reduce nitrate leaching.

\subsubsection{Gaseous emissions}

Legumes have the potential to directly and indirectly reduce emissions of greenhouse gases and nutrients. Legumes indirectly reduce emissions of carbon dioxide as BNF saves the fossil energy resources required for manufacture of synthetic $\mathrm{N}$ fertilizers. Compared to cereals or pastures fertilized with $\mathrm{N}$, 
legumes and legume-based pastures can reduce fossil energy use by 35 to $60 \%$ (Jensen et al. 2011). Using a life cycle assessment (LCA) approach, the introduction of grain legumes into crop rotations has been estimated to reduce the emissions of ammonia by about $25 \%$ and nitrous and nitrogen oxides by about $10 \%$ (Nemecek and Baumgartner 2006; Cederberg and Flysiö 2004). In a review, Jensen et al. (2011) calculated average $\mathrm{N}_{2} \mathrm{O}$ emissions from grain legumes of $1.23 \mathrm{~kg} \mathrm{~N}_{2} \mathrm{O}-\mathrm{N}$ ha $^{-1}$ compared to $2.71 \mathrm{~kg} \mathrm{~N}_{2} \mathrm{O}-\mathrm{N}$ ha ${ }^{-1}$ from annual non-legume crops using data from 71 site-years of crop experiments.

\subsection{Soil improvement}

Grain legumes have the potential to increase soil organic matter (Leithold et al. 1997) and improve soil structure through deep rooting of some species, for example lupin and low $\mathrm{C} / \mathrm{N}$ ratios of crop residues that are closer to that of soil properties than non-legume crops (Jensen et al. 2011). Switching from cereal monoculture and conventional tillage practices to a rotation with legume crops and reduced tillage is reported to stimulate the accumulation of $0.5-1.0 \mathrm{t} \mathrm{ha}^{-1}$ of soil organic carbon annually, with the legume component of the cropping sequence contributing up to $20 \%$ of the carbon gain (Leithold et al. 1997; West and Post 2002; Wu et al. 2003; Hernanz et al. 2009).

The impact of grain legumes to soil structure and organic matter and their pest control service (see Section 4.2) is difficult to quantify in economic terms. However, some grain legumes can be introduced into reduced or zero tillage systems which reduce production costs substantially compared to ploughing. These cost savings are greatest when the change in tillage is combined with the diversification of the crop rotation by including a legume (Luetke-Entrup et al. 2006). In Mediterranean production systems, reduced tillage with grain legumes has shown especially positive economic effects due to increased water retention that often enhance crop yields (e.g. Lopez-Bellido et al. 2010; Sánchez-Girón et al. 2004; Soldevilla-Martinez et al. 2013).

\subsection{Phosphorus mobilization}

Phosphorus can be a major limiting factor for plant growth because of its low availability due to slow diffusion and high fixation in soils (Shen et al. 2011). Legumes are able to solubilize soil phosphorus through releasing root exudates that contain up to eight carboxylic acids (Egle et al. 2003). This can improve the phosphorus $(\mathrm{P})$ uptake of a cereal grown intercropped in a mixture ( $\mathrm{Li}$ et al. 2007) and also in cereals grown after a legume crop (Nuruzzaman et al. 2005). The deep rooting characteristics of some species such as lupin also contribute to efficient nutrient uptake from deep soil layers (Jensen and Hauggaard-Nielsen 2003). However, the amounts of phosphorus mobilization are small compared to their phosphorus demand and vary depending on genotype and environment and can therefore be neglected in economic analysis.

\subsection{Emission reductions from animal production}

LCA studies have compared livestock products produced using European-grown grain legumes with products from soybean-based feed (Cederberg and Flysiö 2004; Eriksson et al. 2004; van der Werf et al. 2005; Baumgartner et al. 2008; Topp et al. 2012). Partially replacing imported soybean with EU-produced field pea, faba bean or lupin in feed rations has been shown to significantly reduce energy demand, GHG emissions and acidification potential —other EU-produced legume crops may have a similar potential. Furthermore, onfarm feeding of home-grown legumes reduces transport and facilitates nutrient cycling between crops, animals, manure and soil (Baumgartner et al. 2008; Cederberg and Flysiö 2004; Eriksson et al. 2004). However, the feed quality of onfarm-produced mixtures may be lower than that from feed compounders due to limited options to optimize feed rations. Baumgartner et al. (2008) suggested that current feed optimization models defining the most cost-effective feeds should be extended to include environmental optimization criteria. However, even a significant increase in European production of grain legumes would only satisfy a small share of the European feed demand at current levels of crop yield, animal production and consumption.

\section{Impact of subsidies and other policies on the European Union}

\subsection{History of direct subsidies for legumes}

Support for grain legume production in the EU (Table 2) was initiated in the 1970s and focused on feed production, whereas grain legumes for food uses were not supported until the beginning of the 1980s (EEC 1974; EEC [Council of the European Communities] 1978; EEC [Council of the European Communities] 1989). With the MacSharry reform of 1992, price support was gradually replaced with an area payment in the form of a uniform basic amount multiplied with region-specific reference yields (EEC 1992). Since this regulation classified soybean as an oilcrop, it received far less subsidy than the other grain legumes classified as protein crops. The 1992 Blair House Agreement between the EU and the USA placed a number of restrictions on the support of certain oilseeds, including soybean, and limited the supported area to $5.5 \mathrm{M}$ ha (EC-DG Agri 2011). It also allowed imports of protein crops and oilseeds without import levies. However, by the time the Blair House Agreement was 
implemented, soybean production was already contracting due to structural changes in agriculture in south-eastern Europe.

Between 2005 and 2006, all coupled payments were gradually replaced by regional Single Payment Scheme (EC 2003a). France and Spain made use of an exceptional rule allowing them to retain $25 \%$ of the coupled payments until 2010. Protein crops were supported further by the 'protein premium' of $56 € \mathrm{ha}^{-1}$ in 17 member states until 2012 (Austria, Belgium, Denmark, Finland, France, Germany, Greece, Ireland, Italy, Luxembourg, Malta, the Netherlands, Portugal, Slovenia, Spain, Sweden and the UK). Five member states (Lithuania, Slovenia, Hungary, Estonia and Poland) used Complementary National Direct Payments (CNDP) for new member states to support legumes (LMC International 2009a). Many regionally important grain legumes such as common bean and groundnut have never received EU-wide support.

The introduction of the Single Payment Scheme in the CAP has improved the relative profitability of grain legumes in low-yielding compared to high-yielding regions (LMC International 2009a; Kamp et al. 2010). As a result, field pea production areas increased in some countries with very low field pea yields, e.g. Greece and Spain, and areas declined in most other countries including some with very high field pea yields such as Belgium, France and the UK (Eurostat 2015). This development is reflected in a strong reduction in the average yield of grain legumes in the EU.

\subsection{Subsidies to competing crops}

Other policies have indirectly affected the economic attractiveness of legume crop production. The biofuel blending mandate, biofuel tax exemption (EC [Council of the European Union] 2003b; EC [Council of the European Union] 2003c) and incentive schemes for biofuel plants have indirectly supported the production of rapeseed processed to biodiesel and rapeseed meal. From 2004 to 2009, the CAP awarded a carbon-credit payment to biofuel producers of 45 $€ \mathrm{ha}^{-1}$ (Robles 2011; Peri and Baldi 2013). In addition, increases in world market price of soybean in 2007 increased demand for the by-products of oil extraction for biodiesel, i.e. sunflower and rapeseed meal. As a consequence, production of bioenergy crops has increased greatly in the EU, and it can be assumed that grain legumes are among the crops replaced by these bioenergy crops and their by-products. For example, rapeseed acreage increased 600-fold in Romania in 2000 2009, whereas the soybean area decreased by almost $60 \%$ (Popescu 2012). On a European scale, rapeseed and sunflower areas increased by $43 \%$ from 2000-2013 while grain legume (incl. soybean) areas reduced by $33 \%$ in the same period (FAOstat 2015).

\subsection{Coupled support in the current and reformed Common Agricultural Policy}

Under the current Common Agricultural Policy (CAP), there are very few market measures supporting grain legumes, except for a tariff on faba bean (3.2\%) and sweet lupin (2.5\%) (EC-DG Agri 2011). Direct support schemes exist under Pillar 1 (Council Regulation (EC) No. 73/2009, Art. 68; EC 2009). Member states may choose to provide direct payments for specific crops of up to $10 \%$ of their annual national ceiling for agricultural subsidies. This is applied e.g. by Finland (78 $€ \mathrm{ha}^{-1}$ in 2011), France (140€ $\mathrm{ha}^{-1}$ in 2011), Spain, Poland $\left(163 € \mathrm{ha}^{-1}\right.$ in 2012), Lithuania and Slovenia. With the recent reform of the CAP, the option for voluntary coupled support was maintained (Regulation (EU) No. 1307/2013, Art. 52 and 53; EU 2013b), but the maximum volume is reduced to $8 \%$ of the national ceilings or $13 \%$ in specific cases. The scheme targets sectors, regions or types of farming that are 'particularly important for economic, social or environmental reasons [and] undergo certain difficulties' (Art. 52), including protein crops, other grain legumes and dried fodder including forage legumes. As an incentive to apply this support to 'maintain the protein-based autonomy' (Art. 1 §49) in livestock production, the maximum volume for coupled support can be increased by $2 \%$ of the national ceiling when at least $2 \%$ are used for supporting the production of protein crops (Art. 53). If fully taken up by member states, such schemes could have a significant impact on legume production, although the subsidy per hectare required to incentivize legume production may be high in some regions (Bues et al. 2013). This support scheme could also be applied, depending on approval by the European Commission, to support grain legume production for food markets. These provide an economic niche that would increase profitability of legume production, e.g. food pulses especially in Mediterranean regions or guaranteed GM-free food soybean.

\subsection{Greening under the reformed Common Agricultural Policy}

Under the reformed CAP, $30 \%$ of direct payments to farmers (under pillar 1) are bound to the 'greening component' (Regulation (EU) No. 1307/2013, Art. 43; EU 2013b) to support 'agricultural practices beneficial to the climate and the environment' (Art. 1, §37), including two requirements that may support legume cultivation. 'Crop diversification' (Art. 44) requires farm holdings with $10-30$ ha of arable land to cultivate at least two crops. Holdings with more than 30 ha are required to cultivate at least three crops, with the largest one and two crops covering not more than 75 and $95 \%$ of the arable land, respectively. It is projected that these requirements will have a negligible effect on crop diversification towards legumes (Westhoek et al. 2011; European Society of 
Table 2 Key policies related to grain legume production in the EU

Year Regulation Policy change

1974 Regulation (EEC) No 1900/74 of the Council of 15 July 1974

1978 Council Regulation (EEC) No 1119/78 of 22 May 1978

1989 Council Regulation (EEC) No 762/89 of 20 March 1989

1992 Council Regulation (EEC) No 1765/92 of 30 June 1992

2003 Council Regulation (EC) No 1782/2003 of 29 September 2003

2005 Council Regulation (EC) No. 1698/2005 of 20 September 2005

2009 Council Regulation (EC) No 73/2009 of 19 January 2009

2013 Regulation (EU) No. 1305/2013 and No. 1307/2013 of the European Parliament and of the Council of 17 December 2013
Introduction of price support to soybean producers

Introduction of price support to producers of pea, lupins and faba bean for feed uses, in 1982 for the same crops for food use

Introduction of uniform area support for producers of chickpea, lentils and vetch grain (gradually increased from 75 to $181 \mathrm{ECU} \mathrm{ha}{ }^{-1}$ ), maintained until 2006

MacSharry reform: Reduction of price support and gradual replacement with regionally uniform area payments. Lower support for oilcrops (incl. soybean) than for protein crops (pea, faba bean, lupins)

Inclusion of all area payments into the single payment scheme. Introduction of uniform area premiums for protein crops (pea, faba bean, lupins)

\section{programme}

Art. 68: Introduction of optional direct support schemes for specific crops

CAP reform: Introduction of 'greening component' to direct payments including diversification requirements and ecological focus areas, reform of rural development programme and voluntary direct support schemes

References: EEC [Council of the European Communities] 1974, EEC [Council of the European Communities] 1978, EEC [Council of the European Communities] 1989, EEC [Council of the European Communities] 1992; EC [Council of the European Union] 2003a, 2005, EC [Council of the European Union] 2009; EU, Union] 2013a, EU [European Union] 2013b

Agronomy 2012) as most farms already comply and they do not encourage diversity between main types of crops such as cereals, oilcrops and legumes. There are also several exemptions, e.g. farm holdings with a large share of fallow, forage production or farms situated in the far north of the Union (Art. 44).

The second component requires farm holdings with more than 15 ha to establish 'ecological focus areas' (EFAs) on $5 \%$ of the eligible arable land, with some exceptions (EU 1307/2013, Art. 46; EU 2013b), in order to 'safeguard and improve biodiversity on farms' (Art. $1 \S 44)$. Besides nonharvestable uses such as fallow and landscape features, EFAs may include, among others, cover crops and 'nitrogenfixing crops' (Art. 46, §2), which are subject to weighting factors (EC [European Commission] 2014a, 2014b). Cultivation of legumes is weighted by the factor 0.7 , which is higher than for other harvestable uses of EFAs. Thus, a 100ha farm is required to grow almost 8 ha of legumes, or almost 16 ha of crops with cover crops (factor 0.3 ), or between 2.5 and 5 ha of fallow, agro-forestry or landscape features, among others (factors between 1.0 and 2.0). Member states are required to provide lists of $\mathrm{N}$-fixing crops considered to benefit biodiversity and define accepted production methods. Input use is not restricted for legumes as EFAs in Germany. The increase in grain legume production areas in Germany in 2015 (BMEL 2015) was attributed to the incentivizing effect of the EFA requirements. This increase occurred even though other options such as cover cropping may be simpler.

\subsection{Support to sustainable farming practices}

The CAP's second pillar, the Rural Development Programme (Regulation (EU) No. 1305/2013; EU 2013a), encompasses support to producer groups, agri-environment-climateschemes and support to organic farming (Art. 27, 28 and 29); all of which have potential relevance for the promotion of legumes. Overall, the second pillar support amounts to 13 billion $€$ per year for all Rural Development Programmes in the EU-28 (2014-2020; EU 2013b) and is therefore smaller in financial terms than direct support under the first pillar.

Table 3 shows ten EU member states that have agrienvironment schemes that encompass legume production among their requirements or have the potential to indirectly support legume production. The reformed CAP provides for a maximum annual support of 600 or $900 € \mathrm{ha}^{-1}$ for annual and perennial crops, respectively (EU 2013b, Art. 28). The ecological effectiveness of such policies clearly depends on the individual scheme's design and is under debate (Kleijn et al. 2001; Marggraf 2003; van Hecken and Bastiaensen 2010; Uthes and Matzdorf 2013). However, as the decision to include legumes in the requirements is at the discretion of member states or regional authorities, the overall volume of support to legumes via this measure is comparably small, but may be very relevant in specific regions (Bues et al. 2013).

Organic production systems are expanding in the EU, with the share of certified organic area growing from $3.6 \%$ in 2005 to $5.8 \%$ in 2013 (EUROSTAT 2015). In organic agriculture, 
Table 3 Overview on agri-environment schemes in selected EU member states (date of information April 2013)

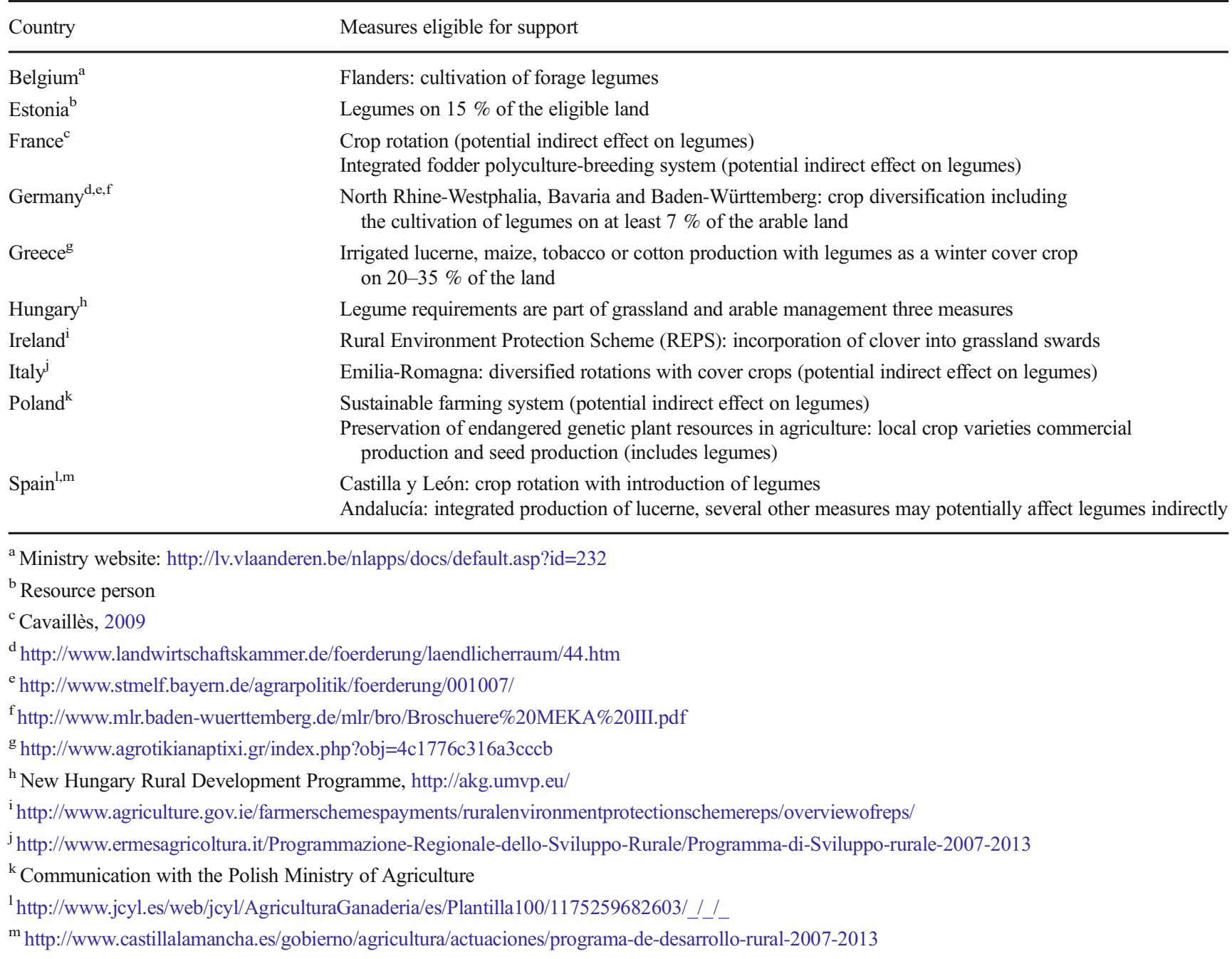

the exclusion of synthetic fertilizers makes legumes essential (Watson et al. 2002). Therefore, the rules of organic production include the premise that 'the fertility and biological activity of the soil shall be maintained and increased by multiannual crop rotation including legumes and other green manure crops' (EC 2007, Art. 12b). Hence, legumes are considerably more widespread on organic than on conventional land, e.g. grain legumes (incl. soybean) were grown on $6.8 \%$ of the organic arable area in 2013, about fourfold of their area share in conventional farming (EUROSTAT 2015). Conversion to and maintenance of organic farming is supported by several EU member states at a regional or national level, with the same maximum amounts applying as for agrienvironment schemes (EU 2013b, Art. 29). The costs for supporting organic farming may be high but are partly paid by the consumers of organic products (Bues et al. 2013). Organic farming also benefits from the CAP reform in that organic farmers complying with the EU-organic farming regulations receive the 'greening' component of direct payments without specific conditions (EU 2013a, Art. 38).

Lastly, Rural Development Programmes can be applied to support the initiatives of producers, processors and market development for legume production or production of livestock with domestic protein feeds (maximum financial volume 100, $000 €$ annually per measure).

\subsection{Support outside the Common Agricultural Policy}

Public support for legume cultivation can also come from outside the CAP. Support to research, breeding and technical progress in agriculture can bring substantial returns (Fuglie and Heisey 2007), and legumes are responsive to technical and breeding improvements (Zerhusen-Blecher and Schäfer 2013). The small size of the legume sector results in market failure in commercial plant breeding and technology development in this sector (Moran et al. 2007; Wiggering et al. 2012). 
Research and associated knowledge exchange programmes can help to improve the understanding and awareness of the economic and agronomic effects of legume production, described in Section 3. The successful development of the legume sectors in Canada and Australia has been greatly supported by extensive public agronomic research on these crops (Zentner et al. 2002; LMC International 2009a). Also, climate protection and nutrient policies could improve the attractiveness of legumes based on their non-market outputs (Section 3.3), e.g. through strengthening the current greenhouse gas cap-and-trade policy, installation of taxes on carbon or nutrients or harnessing of the Nitrates Directive, the Water Framework Directive or related national regulations. The Nitrates Directive together with other agricultural policies in the milk sector has already improved the relative economic performance of white clover-supported dairy production (Rochon et al. 2004).

\section{Outlook}

In order to meet the future demands for agricultural production while sustaining natural resources and improving environmental quality, future agriculture needs to be productive, resource-efficient and support biodiversity. At the current level of technology, legume-supported crop rotations can make a significant contribution to this as they demand less inputs than many crops, show a high level of resource use efficiency and support biodiversity.

Our analysis of marketed and non-marketed outputs of legume cultivation and related factors has exposed the mechanisms that have led to the decline of grain legumes in European agriculture. In the case of market outputs, competitive imported protein and the yield uncertainties of legumes have reinforced the relative higher profitability of cereals and hence their comparative advantage. There is a lack of mechanisms for valuing and rewarding the non-marketed products of grain legumes such as biodiversity as well as a lack of recognition of the system level internal effects of products such as biologically fixed nitrogen. Thus, current market mechanisms continue to support the trend towards specialization.

Increasing legume cultivation in Europe would support environmental improvement and resource use efficiency at a range of scales, from the field to the global. Their pre-crop effect, nitrogen provision and potential to improve nutrient conservation and biodiversity improve the sustainability of farm productivity while saving resources and reducing emissions. Against this background, it is important to discuss the possible measures to increase economic incentives for legume cropping and to facilitate their increased presence in European farmland.

\subsection{Improving marketed outputs}

Returns from marketed output of legumes or any other crop depend primarily on its yield and price. A continuing increase in soybean feed prices is expected due to the growing international requirements and a shift in demand towards GM-free produce. This could improve prices of EU-grown legumes and increase the gross margin of legume cultivation. In the absence of significant price increase of possible protein substitutes, yield improvements relative to other crops may be the most effective measure to improve the relative profitability of grain legumes. Key agronomic constraints that need to be addressed in order to increase grain legume productivity include (1) temporal yield stability, (2) pest, disease and weed management, and (3) improved crop rotation design to maximize rotational effects. The first two depend on breeding advances. Promising agronomic innovations include (1) soybean cultivation under cool growing conditions (Zimmer et al. 2016), (2) improved agronomy through on-farm research (Bloch et al. 2015) and (3) intercropping of grain legumes with cereals (Bedoussac et al. 2015).

Prices and demand for legumes can also be increased by exploiting niches for their production and marketing. Voisin et al. (2014) illustrate the development of regional specialty niches for selected lentil and bean varieties in regions of France that are supported through public labels such as protected geographical indication. Demand for high-value food grain legumes has stabilized their production in Mediterranean countries (see Section 3.2) and contributed to the high competitiveness of field pea and lentil production in Canada (LMC International 2009a; Zentner et al. 2002) and of chickpea production in Australia (Schilizzi and Kingwell 1999). Innovative examples of legume processing include the use of lupin in a number of new vegan products, e.g. PlantsProFood (Pro Lupin 2014), or the non-food sector, e.g. renewable resources for bio-refineries (Papendiek et al. 2012; Papendiek and Venus 2014). Another marketing possibility is provided by the increasing demand for organic food, as legumes are considerably more widespread in organic agriculture than on conventionally farmed land (see Section 6.5). Furthermore, grain legumes are a valuable component of crop rotations using reduced or zero tillage systems and increase the ability of this production system to save production costs (see Section 5.4). Growing consumer awareness of environmental performance of products offers further opportunities. In the same way that consumers are willing to pay for organic production methods, there may be a willingness to pay higher prices to reward lower impact production methods and products with less 'food-miles'. The use of eco-labelling schemes could be a promising option here. Meynard et al. (2013) propose several levers that can be used to promote the development of grain legumes at different levels in the value chain providing examples from France. For field pea, they suggest 
(i) enhancing crop performance through technical and genetic improvements, demonstrating the effects on a rotation scale and developing regulatory incentives, and (ii) avoiding regular commodity markets by using varieties with specific qualities, reorganizing links between plant and animal supply chains and developing new outlets such as human nutrition.

\subsection{Support for non-market outputs}

\subsubsection{Awareness among producers}

In the case of non-market outputs of legume cultivation, the $\mathrm{N}$ supply, break crop effects, yield increases and cost-savings potential in subsequent crops are often disregarded at farm level. The rotation effects of legumes may be worth more than $100 € \mathrm{ha}^{-1}$ (von Richthofen et al. 2006) but this increased economic performance is reflected in the gross margins of the subsequent crop, causing underestimation of the economic performance of grain legumes compared to alternative crops (Schneider 2008). To this end, modified gross margin analysis and new methods to evaluate legumes at the cropping system scale have been proposed by Reckling et al. 2015b, in press. In addition, a gradual increase in fertilizer-to-product price ratios will increase the relative economic performance further.

\subsubsection{Policy}

Agricultural policy has not realized its potential to reverse the decline in legume crop production. Policies to boost oilseed crop production for biofuels support or maintain conditions unfavourable for grain legumes. In France, Meynard et al. (2013) showed that providing direct subsidies did not lead to any structural change in the competitiveness of grain legumes. The current and post-reform CAP entails several options to support legumes based on their environmental effects, i.e. through greening requirements, through inclusion in agrienvironment schemes or through support for organic farming. National policy will influence the production of grain legumes by deciding on the support for competing options for the targeting of environmental-based support. However, stronger mechanisms that extent beyond the CAP are required to adequately value non-market outputs of legumes, like overall policies on climate protection, biodiversity conservation and nutrient policies.

Dequiedt and Moran (2015) evaluated greenhouse gas abatement costs from an increased area of legumes in France and found that up to $0.8 \mathrm{Mt} \mathrm{CO}_{2}$ eq. could be mitigated for an average cost of $14 € / \mathrm{t} \mathrm{CO} 2$ eq. Higher mitigation targets would be associated with continuously increasing costs per additional $\mathrm{t}-\mathrm{CO}_{2}$ eq. This example shows that legume-supported diversified production systems can be a low-cost mitigation option for national abatement goals. In order to tap any future carbon market opportunities, farmers need mechanisms that realize the value of carbon credits that they generate at farm level similar to those available for biofuel crops (Robles 2011). Nevertheless, Dequiedt and Moran (2015) report that current low prices of carbon credits ( $\$ 5 /$ tonne) may not sufficiently motivate farmers to increase legume cultivation.

\section{Conclusions}

Simplification and specialization trends in response to market signals in agro-ecosystems have weakened the position of legumes in Europe. This review provides valuable insights in their decline and offers possibilities for their revival. It is possible to improve the relative profitability of legumes in terms of marketed products by (1) devising policies aimed at increasing the prices of legume products, such as import restrictions of GM soybean or tariffs, (2) taking actions that reduce yield variability e.g. through investment in breeding and by (3) restricting the policies such as biofuel blending mandates that influence the relative profitability of the competing crops. In the case of non-market outputs and services, these are decisive in the argument to diversify cropping systems by including leguminous crops. The disregard of ecosystem services such as BNF and pest control, break crop effects and the absence of mechanisms to monetize the emission reduction and biodiversity enhancement services lead to suboptimal levels of economic returns from these services. It is also important to increase awareness of break crop effects as well as BNF gains from legume cultivation among farmers. Increased fertilizer-to-product price ratio can also influence their appreciation. In addition, methods to increase consumer awareness of environmental impacts of different production options can be explored.

The inherent combination of commodity outputs, non-market outputs and positive external impacts of legumes provides a rationale for public investment in long-term research to improve the internal outputs and their perception and CAP reforms aimed at rewarding the non-market outputs such as biodiversity enhancement and emission reduction. Increasing the nonmarket outputs under the Greening regulation and augmenting support to organic production systems probably will realize a significant increase in legume production in the EU. Nevertheless, development of niche markets, reforms in environmental policies, new mechanisms to appreciate non-market outputs including payment for ecosystem services and carbon markets, increased investment in research and development of legumes and increased flow of information on farming system effects are required to turn around the current decline of legumes in European landscapes. 


\section{References}

Alpmann D, Braun J, Schäfer BC (2013) Analyse einer Befragung unter erfolgreichen Körnerleguminosenanbauern im konventionellen Landbau. Erste Ergebnisse aus dem Forschungsprojekt LEGUAN. In: Im Fokus: Heimische Körnerleguminosen vom Anbau bis zur Nutzung. DLG Wintertagung, 15.-17. January 2013 Berlin. http:// www4.fh-swf.de/media/downloads/forschung/leguan/03 Analyse einer_Befragung_unter_erfolgreichen Koernerleguminosenanbauern_im_konventionellen_Landbau.pdf. Accessed 4 March 2014

Amjath-Babu TS, Kaechele H (2015) Agricultural system transitions in selected Indian states: what do the related indicators say about the underlying biodiversity changes and economic trade-offs? Ecological Indicators 57:171-181

Aramyan LH, van Wagenberg CPA, Backus GBC (2009) EU policy on GM soy; Impact of tolerance threshold and asynchronic approval for GM soy on the EU feed industry. Report 2009-052. The Hague: LEI Wageningen UR. http://edepot.wur.nl/7856. Accessed 3 March 2013

Ayaz S, McKenzie BA, Hill GD, McNeil DL (2004) Variability in yield of four grain legume species in a subhumid temperate environment I. Yields and harvest index. J Agr Sci 142:9-19

Bachinger J, Zander P (2007) Rotor, a tool for generating and evaluating crop rotations for organic farming systems. Eur J Agron 26:130 143. doi:10.1016/j.eja.2006.09.002

Baumgartner DU, de Baan L, Nemecek T (2008) European grain legumes - environment-friendly animal feed? Life cycle assessment of pork, chicken meat, egg, and milk production. Grain Legumes Integrated Project (GLIP). New strategies to improve grain legumes for food and feed. Food quality and safety. WP2.2, Environmental Analysis of the Feed Chain, Final Report. Agroscope ReckenholzTänikon Research Station (ART), Zürich. http://kurzlink.de/ Baumgartner-et-al-08. Accessed 4 March 2014

Baumgärnter S (2007) The insurance value of biodiversity in the provision of ecosystem services. Natural Resource Modeling 20(1):87127

Bedoussac L, Journet E-P, Hauggaard-Nielsen H, Naudin C, CorreHellou G, Jensen ES, Prieur L, Justes E (2015) Ecological principles underlying the increase of productivity achieved by cereal-grain legume intercrops in organic farming. A review. Agronomy for Sustainable Development 35:911-935. doi:10.1007/s13593-0140277-7

Bertoglio JC, Calvo MA, Hancke JL, Burgos RA, Riva A, Morazzoni P, Ponzone C, Magni C, Duranti M (2011) Hypoglycemic effect of lupin seed $\gamma$-conglutin in experimental animals and healthy human subjects. Fitoterapia 82:933-938. doi:10.1016/j.fitote.2011.05.007

Bindraban PS, Rabbinge R (2011) European food and agricultural strategy for 21 st century. International Journal of Agricultural Resources, Governance and Ecology 9:80-101

Bloch R, Knierim A, Häring A-M, Bachinger J (2015) Increasing the adaptive capacity of organic farming systems in the face of climate change using action research methods. Organic Agriculture 1-13. doi:10.1007/s13165-015-0123-5

von Blottnitz H, Rabl A, Boiadjiev D, Taylor T, Arnold S (2006) Damage costs of nitrogen fertilizer in Europe and their internalization. $\mathrm{J}$ Environ Plan Manage 49:413-433. doi:10.1080/ 09640560600601587

BMEL [Bundesministerium für Ernährung und Landwirtschaft] (2015) Ernte 2015: Mengen und Preise. BMEL [Bundesministerium für Ernährung und Landwirtschaft] report of 27.8.2015, 29pp. http:// www.bmel.de/SharedDocs/Downloads/Landwirtschaft/MarktStatistik/Ernte2015Bericht.pdf? blob = publicationFile. Accessed 1 November 2015 de Boer J, Helms M, Aiking H (2006) Protein consumption and sustainability: diet diversity in EU-15. Ecol Econ 59:267-274. doi:10. 1016/j.ecolecon.2005.10.011

Brouwer F (2006) Main trends in agriculture. In: Agriculture for sustainable development: a dialogue on societal demand, pressures and options for policy. SASSPO-SSP4-022698. Background Note 1. Available from: http://www.mtt.fi/sasspo/SASSPO_HKI BN1-1. pdf. Accessed 4 March 2014

Bues A, Preissel S, Reckling M, Zander P, Kuhlmann T, Topp K, Watson C, Lindström K, Stoddard FL, Murphy-Bokern D (2013) The environmental role of protein crops in the new common agricultural policy. In: Agriculture and rural development. European Parliament, Brussels, Available from: http://edepot.wur.nl/262633. Accessed 4 March 2014

Cavaillès E (2009) La rélance des légumineuses dans le cadre d'un plan protéine: Quels bénéfices environnementaux? In: Études and documents: Service de l'Économie, de l'Évaluation et de l'Intégration du Développement Durable, Commissariat Général au Développement Durable, $\mathrm{N}^{\circ}$ 15. http://www.developpement-durable.gouv.fr/IMG/ pdf/E_D15.pdf.Accessed 4 March 2014

Cederberg C, Flysiö A (2004) Environmental assessment of future pig farming systems. Quantifications of three scenarios from the food 21 synthesis work. In: SIK-rapport Nr 723 2004. Göteborg: SIK. http:// www.vaxteko.nu/html/sll/institutet livsm bioteknik/sik-rapport/ SIK723/SIK 723.PDF. Accessed 4 March $2 \overline{0} 14$

Cederroth CR, Nef S (2009) Soy, phytoestrogens and metabolism: a review. Molecular and Cellular Endocrinology 304:30-42

Cernay C, Ben-Ari T, Pelzer E, Meynard J-M, Makowski D (2015) Estimating variability in grain legume yields across Europe and the Americas. Scientific Reports 5:11171. doi:10.1038/srep11171

Chalk PM (1998) Dynamics of biologically fixed N in legume-cereal rotations: a review. Aust J Agric Res 49:303-316. doi:10.1071/ A97013

Charles R, Vuilloud P (2001) Pois protéagineux et azote dans la rotation. Rev Suisse Agric 33:365-370

Dachler M, Köchl A (2003) Der Einfluss von Fruchtfolge, Vorfrucht, Stickstoffdüngung und Einarbeitung der Ernterückstände auf Ertrag und Rohproteingehalt von Winterweizen und nachfolgender Sommergerste. Die Bodenkultur 54:23-34

Davis AS, Hill JD, Chase CA, Johanns AM, Liebman M (2012) Increasing cropping system diversity balances productivity, profitability and environmental health. PLoS ONE 7(10):e47149. doi:10. 1371/journal.pone.0047149

Davis J, Sonesson U, Baumgartner DU, Nemecek T (2010) Environmental impact of four meals with different protein sources: case studies in Spain and Sweden. Food Res Int 43:1874-1884. doi: 10.1016/j.foodres.2009.08.017

Defra. Fertiliser manual (RB209) 8th edition 2010. TSO, Norwich.

Dequiedt B, Moran D (2015) The cost of emission mitigation by legume crops in French agriculture. Ecological Economics 110:51-60

Döring TF (2015) Grain legume cropping systems in temperate climates. In: De Ron AM (ed) Grain legumes, vol 10, Handbook of plant breeding. Springer Science+Business Media, New York, pp 401434. doi:10.1007/978-1-4939-2797-5 13

EC [Council of the European Union] (2003a) Council Regulation (EC) No 1782/2003 of 29 September 2003 establishing common rules for direct support schemes under the common agricultural policy and establishing certain support schemes for farmers. Official Journal of the European Union L 270:1-69

EC [Council of the European Union] (2003b) Council Directive 2003/96/ EC of 27 October 2003: restructuring the community framework for the taxation of energy products and electricity. Official Journal of the European Union L 283:51-70

EC [Council of the European Union] (2003c) Directive 2003/30/EC of the European Parliament and of the Council of 8 May 2003 on the 
promotion of the use of biofuels or other renewable fuels for transport. Official Journal of the European Union L 123:42-46

EC [Council of the European Union] (2005) Council Regulation (EC) No 1698/2005 of 20 September 2005 on support for rural development by the European Agricultural Fund for Rural Development (EAFRD). Official Journal of the European Union L 277: 1-40

EC [European Commission] (2007) Council Regulation (EC) No 834/ 2007 of 28 June 2007 on organic production and labelling of organic products and repealing Regulation (EEC) No 2092/91. Official Journal of the European Union L 189:1-23

EC [Council of the European Union] (2009) Council Regulation (EC) No. 73/2009 of 19 January 2009 establishing common rules for direct support schemes for farmers under the common agricultural policy and establishing certain support schemes for farmers. Official Journal of the European Union L 30:16

EC [European Commission] (2014a) Commission Delegated Regulation (EU) No 639/2014 of 11 March 2014 supplementing Regulation (EU) No 1307/2013 of the European Parliament and of the Council establishing rules for direct payments to farmers under support schemes within the framework of the common agricultural policy and amending Annex X to that Regulation. Official Journal of the European Union L 181:1-47

EC [European Commission] (2014b) Commission delegated regulation (EU) No $1001 / 2014$ of 8 July2014 amending Annex X to Regulation (EU) No 1307/2013 of the European Parliament and of the Council establishing rules for direct payments to farmers under support schemes within the framework of the common agricultural policy. Brussels. http://ec.europa.eu/agriculture/cap-post-2013/ implementation/index en.htm. Accessed 30 November 2015.

EC-DG Agri [European Commission - Directorate-General for Agriculture and Rural Development] (2011) Oilseeds and protein crops in the EU. http://ec.europa.eu/agriculture/cereals/factsheetoilseeds-protein-crops en.pdf. Accessed 4 March 2014

EEC [Council of the European Communities] (1974) Regulation (EEC) No 1900/74 of the Council of 15 July 1974 laying down special measures for soya beans. http://eur-lex.europa.eu/LexUriServ/ LexUriServ.do?uri=CELEX:31974R1900:EN:HTML. Accessed 11 April 2013

EEC [Council of the European Communities] (1978) Council Regulation (EEC) No 1119/78 of 22 May 1978 laying down special measures for pea and field beans used in the feeding of animals. http://eur-lex. e uropa.eu/LexUriServ/LexUriserv.do? uri= OJ:L:1978:142:0008:0010:EN:PDF. Accessed 11 April 2013

EEC [Council of the European Communities] (1989) Council Regulation (EEC) No 762/89 of 20 March 1989 introducing a specific measure for certain grain legumes. http://eur-lex.europa.eu/LexUriServ/ LexUriServ.do?uri=CELEX:31989R0762:EN:HTML. Accessed 11 April 2013

EEC [Council of the European Communities] (1992) Council Regulation (EEC) 1765/92 of 30 June 1992 establishing a support system for producers of certain arable crops. http://eur-lex.europa.eu/ $\mathrm{L}$ e x U r i S e r v/ L e x U r i S e r v. d o ? u r i = OJ:L:1992:181:0012:0020:EN:PDF. Accessed 11 April 2013

Egle K, Romer W, Keller H (2003) Exudation of low molecular weight organic acids by Lupinus albus L., Lupinus angustifolius L. and Lupinus luteus L. as affected by phosphorus supply. Agronomie 23:511-518. doi:10.1051/agro:2003025

Eisenhauer N, Milcu A, Sabais ACW, Bessler H, Weigelt A, Engels C, Scheu S (2009) Plant community impacts on the structure of earthworm communities depend on season and change with time. Soil Biol Biochem 41:2430-2443. doi:10.1016/j.soilbio.2009.09.001

Eriksson IS, Elmquist H, Stern S, Nybrant T (2004) Environmental systems analysis of pig production - the impact of feed choice. Int $\mathrm{J}$ Life Cycle Assess 10:143-154. doi:10.1065/lca2004.06.160

EU [European Union] (2013a) Regulation (EU) No. 1305/2013 of the European Parliament and of the Council of 17 December 2013 on support for rural development by the European Agricultural Fund for Rural Development (EAFRD) and repealing Council Regulation (EC) No 1698/2005 Official Journal of the European Union L 347: 487-548

EU [European Union] (2013) Regulation (EU) No. 1307/2013 of the European Parliament and of the Council of 17 December 2013 establishing rules for direct payments to farmers under support schemes within the framework of the common agricultural policy and repealing Council Regulation (EC) No. 637/2008 and Council Regulation (EC) No. 73/2009. Official Journal of the European Union L 347:608-670

European Society of Agronomy (2012) Reform of the Common Agricultural Policy to improve the environment - a Statement from the 12th Congress of the European Society for Agronomy. www. european-agronomy.org/frontpage/item/reform-of-the-commonagricultural-policy-to-improve-the-environment-a-statement-fromthe-12th-congress-of-the-european-society-for-agronomy.html. Accessed 12 Apil 2013

Eurostat (2015) European statistics database. European Commission. http:/ec.europa.eu/eurostat/data/database. Accessed 11 December 2015

Evans J, Scott G, Lemerle D, Kaiser A, Orchard B, Murray GM, Armstrong EL (2003) Impact of legume 'break' crops on the yield and grain quality of wheat and relationship with soil mineral $\mathrm{N}$ and crop N content. Aust J Agric Res 54:777-788. doi:10.1071/ AR02224

FAOstat (2015) Food and Agriculture Organization of the United Nations, Statistics Division. http://faostat3.fao.org/home/E. Accessed 11 December 2015

Flores F, Nadal S, Solis I, Winkler J, Sass O, Stoddard FL, Link W, Raffiot B, Muel F, Rubiales D (2012) Faba bean adaptation to autumn sowing under European climates. Agron Sustainable Dev 32: 727-734. doi:10.1007/s13593-012-0082-0

Fuglie KO, Heisey PW (2007) Economic returns to public agricultural research and development. USDA Economic Research Service. Economic Brief Number 10. www.ers.usda.gov/media/195594/ eb10_1_pdf. Accessed 10 April 2013

Gale FP (2000) Economic specialization versus ecological diversification: the trade policy implications of taking the ecosystem approach seriously. Ecol Econ 34:285-292. doi:10.1016/S0921-8009(00) 00181-6

Galloway JN, Dentener FJ, Capone DG, Boyer EW, Howarth RW, Seitzinger SP, Asner GP, Cleveland CC, Green PA, Holland EA, Karl DM, Michaels AF, Porter JH, Townsend AR, Vorosmarty CJ (2004) Nitrogen cycles: past, present, and future. Biogeochemistry 70:153-226. doi:10.1007/s10533-004-0370-0

Giambalvo D, Stringi L, Durante G, Amato G, Frenda AS (2004) Nitrogen efficiency component analysis in wheat under rainfed. Mediterranean conditions: effects of crop rotation and nitrogen fertilization. In: Cantero-Martínez C, Gabiña D (eds) Mediterranean rainfed agriculture: strategies for sustainability. Mediterranean Agronomic Institute of Zaragoza, Zaragoza, pp 169-173

Gierus M, Koch M, Schulz H (2012) Phytoestrogen carryover into cow's milk from legumes - an overview along the food chain. Berichte über Landwirtschaft 90:354-379. < Go to ISI>://WOS: 000312682100002 Accessed 20 Novemebr 2015

Green A, Brown A, Oram R (1980) Determination of outcrossing rate in a breeding population Lupinus albus L. (white lupin). Plant Breed 84: $181-191$

Hallström E, Börjesson P (2012) Sustainable meat consumption to meet climate and health goals - implications of variations in consumption statistics. In: Corson MS, van der Werf HMG (eds) Proceedings of the 8th International Conference on Life Cycle Assessment in the Agri-Food Sector (LCA Food 2012), 1-4 October 2012. INRA, Saint Malo, France, pp 163-168 
Harland JI, Haffner TA (2008) Systematic review, meta-analysis and regression of randomised controlled trials reporting an association between an intake of circa $25 \mathrm{~g}$ soya protein per day and blood cholesterol. Atherosclerosis 200:13-27. doi:10.1016/j. atherosclerosis.2008.04.006

Hauggaard-Nielsen H, Ambus P, Jensen ES (2003) The comparison of nitrogen use and leaching in sole cropped versus intercropped pea and barley. Nutrient Cycling in Agroecosystems 65:289-300. doi: 10.1023/A:1022612528161

Hauggaard-Nielsen H, Jørnsgaard B, Kinaneand J, Jensen ES (2008) Grain legume-cereal intercropping: the practical application of diversity, competition and facilitation in arable and organic cropping systems. Renew Agr Food 23:3-12. doi:10.1017/ S1742170507002025

van Hecken G, Bastiaensen J (2010) Payments for ecosystem services: justified or not? A political view. Environ Sci Policy 13:785-792. doi:10.1016/j.envsci.2010.09.006

Hernanz JL, Sanchez-Giron V, Navarrete L (2009) Soil carbon sequestration and stratification in a cereal/leguminous crop rotation with three tillage systems in semiarid conditions. Agric Ecosyst Environ 133: 114-122. doi:10.1016/j.agee.2009.05.009

Jensen ES, Hauggaard-Nielsen H (2003) How can increased use of biological N2 fixation in agriculture benefit the environment? Plant Soil 252:177-186. doi:10.1023/A:1024189029226

Jensen ES, Peoples MB, Boddey RM, Gresshoff PM, Hauggaard-Nielsen H, Alves BJR, Morrison MJ (2011) Legumes for mitigation of climate change and the provision of feedstock for biofuels and biorefineries: a review. Agron Sustainable Dev 32:329-364. doi: 10.1007/s13593-011-0056-7

Jensen ES, Peoples MB, Hauggaard-Nielsen H (2010) Faba bean in cropping systems. Field Crops Res 115:203-216. doi:10.1016/j.fcr. 2009.10.008

Jensen CR, Joernsgaard B, Andersen MN, Christiansen JL, Mogensen VO, Friis P, Petersen CT (2004) The effect of lupins as compared with peas and oats on the yield of the subsequent winter barley crop. Eur J Agron 20:405-418. doi:10.1016/S1161-0301(03)00057-1

Kamp J, van Berkum S, Timmer R, van Reeuwijk P (2010) Verkenningnaar de mogelijkheden van eiwithoudende teelten in Europa. Business Unit Akkerbouw, Groene ruimte en Vollegrondsgroenten, Publicatienummer: 412. Wageningen: Praktijkonderzoek Plant and Omgeving, Wageningen UR.

Kirkegaard JA, Christen O, Krupinsky J, Layzell D (2008) Break crop benefits in temperate wheat production. Field Crops Res 107:185195. doi:10.1016/j.fcr.2008.02.010

Kleijn D, Berendse F, Smit R, Gilissen N (2001) Agri-environment schemes do not effectively protect biodiversity in Dutch agricultural landscapes. Nature 413:723-725. doi:10.1038/35099540

Köpke U, Nemecek T (2010) Ecological services of faba bean. Field Crops Res 115:217-233. doi:10.1016/j.fcr.2009.10.012

Kremen C, Miles AF (2012) Comparing biologically diversified with conventional farming systems: what is known about environmental benefits, externalities and tradeoffs among crop productivity and ecosystem services? Ecology and Society 17(4):40

Leithold G, Hülsbergen KJ, Michel D, Schönmeier H (1997) Humusbilanzierung - Methoden und Anwendungen als AgrarUmweltindikator. Schriftenreihe der Sächsischen Landesanstalt für Landwirtschaft 3:19-28

LLH [Landesbetrieb Landwirtschaft Hessen] (2012) Berechnung der Preiswürdigkeit von Einzelfuttermitteln für Schweine nach der Austauschmethode Löhr. Excel-based calculation tool. Landesbetrieb Landwirtschaft Hessen. http://www.ufop.de/agrarinfo/aktuelle-meldungen/berechnung-preiswuerdigkeit-voneinzelfuttermitteln-nach-der-austauschmethode-loehr. Accessed 22 September 2015

Li L, Li S, Sun J, Zhou L, Bao X, Zhang H, Zhang F (2007) Diversity enhances agricultural productivity via rhizosphere phosphorus facilitation on phosphorus-deficient soils. Proc Natl Acad Sci USA 104:11192-11196. doi:10.1073/pnas.0704591104

Lin BB (2011) Resilience in agriculture through crop diversification: adaptive management for environmental change. BioScience 61: 183-193, ISSN 0006-3568, electronic ISSN 1525-3244

LMC International (2009a) Evaluation of measures applied under the common agricultural policy to the protein crop sector. Case study monographs. New York, Oxford, Kuala Lumpur. http://ec.europa. eu/agriculture/eval/reports/protein_crops/case_studies_en.pdf. Accessed 4 March 2014.

LMC International (2009b) Evaluation of measures applied under the common agricultural policy to the protein crop sector. Main report. New York, Oxford, Kuala Lumpur. Available from: http://ec.eur.

Lopez-Bellido RJ, Fontan JM, Lopez-Bellido FJ, Lopez-Bellido L (2010) Carbon sequestration by tillage, rotation, and nitrogen fertilization in a Mediterranean vertisol. Agron J 102:310-318. doi:10.2134/ agronj2009.0165

López-Fando C, Almendros G (1995) Interactive effects of tillage and crop rotations on yield and chemical properties of soils in semi-arid central Spain. Soil Tillage Res 36:45-57. doi:10.1016/01671987(95)00495-5

Luetke-Entrup N, Schneider M, Stemann G, Gröblinghoff F-F, Heißenhuber A, Pahl H, Hülsbergen K-J, Maidl FX, Herr H, Sommer C, Korte K, Brunotte J, Kreye H, Lindwedel V, Zieseniß H, Gienapp C, Schulz RR, Propp J (2006) Bewertung von neuen Systemen der Bodenbewirtschaftung in erweiterten Fruchtfolgen mit Körnerraps und Körnerleguminosen. Abschlussbericht über die Versuchsjahre 2001-2005. Fachhochschule Südwestfalen, Fachbereich Agrarwirtschaft, Soest

Mahmood F (2011) Analysis of the conditions for the development of grain legumes in the Midi-Pyrénées region (France), using the APES-FSSIM-indicators modelling chain. Thesis (Diplome de Doctorat). Systèmes Intégrés En Biologie, Agronomie, Géosciences, Hydrosciences Et Environnement (SIBAGHE). Ecole National Supérieure Agronomique de Montpellier, Montpellier. http://www.iamm.fr/ressources/opac css/doc num. php?explnum_id=5957. Accessed 4 March 2014

Maidl FX, Haunz FX, Panse A, Fischbeck G (1996) Transfer of grain legume nitrogen within a crop rotation containing winter wheat and winter barley. Journal of Agronomy and Crop Science 176(1):4757. doi:10.1111/j.1439-037X.1996.tb00445.x

Marchesi M, Parolini C, Diani E, Rigamonti E, Cornelli L, Arnoldi A, Sirtori CR, Chiesa G (2008) Hypolipidaemic and antiatherosclerotic effects of lupin proteins in a rabbit model. Br J Nutr 100:1-4. doi:10.1017/S000711450894215X

Marggraf R (2003) Comparative assessment of agri-environment programmes in federal states of Germany. Agric Ecosyst Environ 98:507-516. doi:10.1016/S0167-8809(03)00109-9

McAusland L (2015) Spotlight on...soya. Institute of Food Research. http://www.ifr.ac.uk/science-society/spotlight/soya/. Accessed 5 December 2015

Meynard JM, Messéan A, Charlier A, Charrier F, Farès M, Le Bail M, Magrini MB, Savini I, Réchauchère O (2013) Crop diversification: obstacles and levers. Study of farms and supply chains. Synopsis of the study report, INRA. www6.paris.inra.fr/depe/content/download/ 3736/35824/version/1/file/Version+Anglaise+Diversification8pages.pdf. Accessed 29.10.2015

Mishra AK, Lence SH (2005) Risk management by farmers, agribusiness, and lenders. Agr Finance Rev 65:131-148. doi:10.1108/ 00214660580001169

Moran D, Barnes A, McVittie A (2007) The rationale for Defra investment in R\&D underpinning the genetic improvement of crops and animals. Defra report for project IF0101. London: Department for Environment and Rural Affairs. http://randd.defra.gov.uk/Default. a s p x ? M en u $=$ Menu \& M odule $=$ More $\&$ L o c a t i o $n=$ None $\&$ Completed $=0 \&$ ProjectID $=14403$. Accessed 3.11.2013 
Mulligan, D., Bouraoui, F., Grizzetti, B., Aloe, A., 2006. An Atlas of panEuropean data for investigating the fate of agrochemicals in terrestrial ecosystems. Report EUR 22334 EN. Office for Official Publications of the European Communities, Luxembourg, 52 pp.

Nemecek T, Baumgartner DU (2006) Environmental impacts of introducing grain legumes into European crop rotations and pig feed formulas: concerted action GL-Pro. Agroscope Reckenholz-Tänikon Research Station (ART), Zürich

Nemecek T, von Richthofen J-S, Dubois G, Casta P, Charles R, Pahl H (2008) Environmental impacts of introducing grain legumes into European crop rotations. Eur J Agron 28:380-393. doi:10.1016/j. eja.2007.11.004

Noordwijk VM, Swift MJ (1999) Belowground biodiversity and sustainability of complex agroecosystems. In: Gafur A., Susilo FX, Utomo M, Noordwijk VM (eds) Management of Agrobiodiversity in Indonesia for Sustainable Land Use and Global Environmental Benefits. ASB Indonesia report no. 9.8-28. http://www. worldagroforestry.org/Sea/Publications/files/paper/PP0075-04/ PP0075-04-1.PDF. Accessed 4 March 2014

Nuruzzaman M, Lambers L, Bolland MDA, Veneklaas EJ (2005) Phosphorus uptake by grain legumes and subsequently grown wheat at different levels of residual phosphorus fertilizer. Aust J Agric Res 56:1041-1047. doi:10.1071/AR05060

Palmer RG, Perez PT, Ortiz-Perez E, MaaloufF, Suso MJ (2009) The role of crop-pollinator relationships in breeding for pollinator-friendly legumes: from a breeding perspective. Euphytica 170:35-52

Pannell DJ (1999) Social and economic challenges in the development of complex farming systems. Agroforest Syst 45:395-411

Papendiek F, Ende H-P, Steinhardt U, Wiggering H (2012) Biorefineries: relocating biomass refineries to the rural area. Landscape Online 27: 1-9. doi: 10.3097

Papendiek, F. and Venus, J. (2014) Cultivation and fractionation of leguminous biomass for lactic acid production. Chemical and Biochemical Engineering Quarterly 28(3):375-382. doi:10.15255/ CABEQ.2013.1854

Pascual U, Perrings C (2007) Developing incentives and economic mechanisms for in situ biodiversity conservation in agricultural landscapes. Agric Ecosyst Environ 121:256-268. doi:10.1016/j.agee. 2006.12.025

Peltonen-Sainio P, Niemi JK (2012) Protein crop production at the northern margin of farming: to boost or not to boost. Agricultural and Food Science 21:370-383

Peoples MB, Hauggaard-Nielsen H, Jensen ES (2009a) The potential environmental benefits and risks derived from legumes in rotations. In: Emerich DW, Krishnan HB (eds) Nitrogen Fixation in Crop Production. Agronomy Monograph No. 52. Madison USA, pp349-385

Peoples MB, Brockwell J, Herridge DF, Rochester IJ, Alves BJR, Urquiaga S, Boddey RM, Dakora FD, Bhattarai S, Maskey SL, Sampet C, Rerkasem B, Khan DF, Hauggaard-Nielsen H, Jensen ES (2009a) The contributions of nitrogen-fixing crop legumes to the productivity of agricultural systems. Symbiosis 48:1-17. doi: 10.1007/BF03179980

Peri M, Baldi L (2013) The effect of biofuel policies on feedstock market: empirical evidence for rapeseed oil prices in EU. Resour Energy Econ 35:18-37. doi:10.1016/j.reseneeco.2012.11.002

Perrings C (2001) The economics of biodiversity loss and agricultural development in low income countries. In: Lee DR, Barret CB (eds) Tradeoffs or Synergies? Agricultural Intensification, Economic Development and the Environment. CABI Publishing, Wallingford, Oxon, UK; New York, NY pp57-72

Plaza-Bonilla D, Nolot J-M, Raffaillac D, Justes E (2015) Cover crops mitigate nitrate leaching in cropping systems including grain legumes: field evidence and model simulations. Agriculture, Ecosystems and Environment 212:1-12. doi:10.1016/j.agee.2015. 06.014
Popescu A (2012) Research regarding oil seeds crops development in Romania in the EU context. Economics of agriculture 59:129-137, http://purl.umn.edu/123964. Accessed 15 November 2015

Preissel S, Reckling M, Schläfke N, Zander P (2015) Magnitude and farm-economic value of grain legume pre-crop benefits in Europe: a review. Field Crops Research 175:64-79. doi:http://dx.doi.org/10. 1016/j.fcr.2015.01.012

PROLEA (2013) De la production à la consommation. Statistiques des oléagineux et protéagineux. Edition 2012-2013: France, Europe, Monde. La filière francaise des huiles et protéines végétales, Paris

Pro Lupin (2014) PlantsProFood-lupin seeds for the food industry. http://www.plantsprofood.prolupin.de/tl_files/plants_pro_food/ downloads/Broschur-PlantsProFood.pdf. Accessed 12 November 2014

Reckling M, Döring T, Stein-Bachinger K, Bloch R, Bachinger J (2015a) Yield stability of grain legumes in an organically managed monitoring experiment. Aspects of Applied Biology 128:57-62

Reckling M, Hecker J-M, Bergkvist G, Watson C, Zander P, Stoddard F, Eory V, Topp K, Maire J, Bachinger J (2015b, in press) A cropping system assessment framework - evaluating effects of introducing legumes into crop rotations. European Journal of Agronomy

von Richthofen J-S, Pahl H, Bouttet D, Casta P, Cartrysse C, Charles R, Lafarga A (2006) What do European farmers think about grain legumes. Grain Legumes 45:14-15

Riedesser K (2012) Sommerungen 2012 - Welche Kultur lässt den höchsten Deckungsbeitrag erwarten?., Landwirtschaftskammer Rheinland-Pfalz, http://www.lwk-rlp.de/landwirtschaft/ einzelansicht/archive/2012/january/article/sommerungen-2012welche-kultur-laesst-den-hoechsten-deckungsbeitrag-erwarten. Accessed 5 March 2014

Robles R (2011) The economics of oil-seed crops for energy use: a case study in an agricultural European region. Scientific Journal Warsaw University of Life Sciences Problems of World Agriculture 11:115125

Rochon JJ, Doyle CJ, Greef JM, Hopkins A, Molle G, Sitzia M, Scholefield D, Smith CJ (2004) Grazing legumes in Europe: a review of their status, management, benefits, research needs and future prospects. Grass Forage Sci 59:197-214. doi:10.1111/j.1365-2494. 2004.00423.x

Sabais ACW, Scheu S, Eisenhauer N (2011) Plant species richness drives the density and diversity of Collembola in temperate grassland. Acta Oecologica 37:195-202. doi:10.1016/j.actao.2011.02.002

Sánchez-Girón V, Serrano A, Hernanz JL, Navarrete L (2004) Economic assessment of three long-term tillage systems for rainfed cereal and legume production in semiarid central Spain. Soil Till Res 78:35-44. doi:10.1016/j.still.2004.01.001

Sass O (2009) Marktsituation und züchterische Aktivitäten bei Ackerbohnen und Körnererbsen in der EU. Journal für Kulturpflanzen 61:306-308

Sauermann W (2009) Körnerleguminosen konservieren oder silieren. Mit Ackerbohnen, Futtererbsen und Süßlupinen Futterkosten senken. Landwirtschaftliches Wochenblatt Schleswig-Holstein 27:23-24

Schäfer BC (2013) Mit Fruchtfolgen Witterungsrisiken trotzen! Praxisnah 1:5-7

Schilizzi SGM, Kingwell RS (1999) Effects of climatic and price uncertainty on the value of legume crops in a Mediterranean-type environment. Agr Syst 60:55-69. doi:10.1016/S0308-521X(99)00018-9

Schneider A (2008) The dynamics controlling the grain legume sector. Presentation at COPA-COGECA debate on grain legumes, 26 March 2008 Brussels

Shen J, Yuan L, Zhang J, Li H, Bai Z, Chen X, Zhang W, Zhang F (2011) Phosphorus dynamics: from soil to plant. Plant Physiol 156:9971005. doi:10.1104/pp.111.175232

Sirtori CR, Galli C, Anderson JW, Arnoldi A (2009) Nutritional and nutraceutical approaches to dyslipidemia and atherosclerosis 
prevention: focus on dietary proteins. Atherosclerosis 203:8-17. doi:10.1016/j.atherosclerosis.2008.06.019

Sirtori CR, Triolo M, Bosisio R, Bondioli A, Calabresi L, De Vergori V, Gomaraschi M, Mombelli G, Pazzucconi F, Zacherl C, Arnoldi A (2012) Hypocholesterolaemic effects of lupin protein and pea protein/fibre combinations in moderately hypercholesterolaemic individuals. British Journal of Nutrition 107:1176-1183, http:// journals.cambridge.org/download.php?file $=\% 2$ FBJN\%2FBJN107 $08 \% 2 \mathrm{~F} \mathrm{~S} 0007114511004120 \mathrm{a} \cdot \mathrm{pdf} \& \mathrm{code}=$ b2694ced8b4ecb1a6ca4bcf617ba24df. Accessed 15 November 2015

Skuodiene R, Nekrosiene R (2012) The effect of perennials as green manure on cereal productivity and disease incidence. Span J Agric Res 10:44-54. doi:10.5424/sjar/2012101-025-11

Smaling E, Roscoe R, Lesschen J, Bouwman A, Comunello E (2008) From forest to waste: assessment of the Brazilian soybean chain, using nitrogen as a marker. Agric Ecosyst Environ 128:185-197. doi:10.1016/j.agee.2008.06.005

Smil V (2002) Worldwide transformation of diets, burdens of meat production and opportunities for novel food proteins. Enzyme Microb Tech 30:305-311. doi:10.1016/S0141-0229(01)00504-X

Soldevilla-Martinez M, Martin-Lammerding D, Tenorio JL, Walter I, Quemada M, Lizaso JI (2013) Simulating improved combinations tillage-rotation under dryland conditions. Span J Agric Res 11:820 832. doi:10.5424/sjar/2013113-3747

Stemann G, Luetke-Entrup N (2001) Leguminosen korrekt bewerten. Saaten Union. http://archiv.saaten-union.de/index.cfm/article/3453. html. Accessed 5 March 2014.

Stoddard FL, Bond DA (1987) The pollination requirements of the faba bean (Vicia faba L.). Bee World 68:144-152

Topp CFE, Houdijk JGM, Tarsitano D, Tolkamp BJ, Kyriazaki I (2012) Quantifying the environmental benefits of using home grown protein sources as alternatives to soyabean meal in pig production through life cycle assessment. Adv Anim Biosci 3:15

Uthes S, Matzdorf B (2013) Studies on agri-environmental measures: a survey of the literature. Environmental Management 51(1):251-266

de Visser CLM, Schreuder R, Stoddard F (2014) The EU's dependency on soya bean import for the animal feed industry and potential for EU produced alternatives. Oilseeds and fats Crops and Lipids 21: D407. doi:10.1051/ocl/2014021

Voisin A-S, Guéguen J, Huyghe C, Jeuffroy M-H, Magrini M-B, Meynard J-M, Mougel C, Pellerin S, Pelzer E (2014) Legumes for feed, food, biomaterials and bioenergy in Europe: a review. Agronomy for Sustainable Development 34:361-380

Watson CA, Atkinson D, Gosling P, JacksonLR RFW (2002) Managing soil fertility in organic farming systems. Soil Use Manage 18:239247. doi:10.1111/j.1475-2743.2002.tb00265.x

Weitbrecht B, Pahl H (2000) Lohnt sich der Anbau von Körnerleguminosen? Ökologie und Landbau 116:39-41

van der Werf HMG, Petit J, Sanders J (2005) The environmental impacts of the production of concentrated feed: the case of pig feed in Bretagne. Agr Syst 83:153-177. doi:10.1016/j.agsy.2004.03.005

West TO, Post WM (2002) Soil organic carbon sequestration rates by tillage and crop rotation: a global data analysis. Soil Sci Soc Am J 66:1930-1946, kakad0u-10.3334/CDIAC/tcm.002

Westhoek H, Rood T, van den Berg M, Janse J, Nijdam D, Reudink M, Stehfest E (2011) The protein puzzle: the consumption and production of meat, dairy and fish in the European Union. PBL Netherlands Environmental Assessment Agency, The Hague, https://community.oecd.org/servlet/JiveServlet/downloadBody/ 43191-102-1-80819/Protein_Puzzle_web_1.pdf. Accessed 11 April 2013

Westhoek H, Lesschen JP, Rood T, Wagner S, De Marco A, MurphyBokern D, Leip A, van Grinsven H, Sutton MA, Oenema O (2014) Food choices, health and environment: effects of cutting Europe's meat and dairy intake. Global Environmental Change 26:196-205. doi:10.1016/j.gloenvcha.2014.02.004

Westhoff P (2009) The economics of biological nitrogen fixation in the global economy. In: Emerich DB, Krishnan HB (eds) Nitrogen fixation in crop production. American Society of Agronomy, Crop Science Society of America, Soil Science Society of America, Madison, pp 309-328

Westphal C, Steffan-Dewenter I, Tscharntke T (2003) Mass flowering crops enhance pollinator densities at a landscape scale. Ecology Letters 6:961-965. doi:10.1046/j.1461-0248.2003.00523.x

Wiggering H, Bachinger J, Murphy-Bokern et al. (2012). The legumes expert forum: science, economy and society-making ecosystem services from legumes competitive. A research strategy of the German Agricultural Research Alliance (DAFA). DAFA, Braunschweig. http://www.dafa.de/fileadmin/dam uploads/images/ Fachforen/ff_leguminosen-en_2012.pdf Accessed 3 November 2013

Wright I (2008) Research topic review: combinable protein crop production. IOTA Arable Workshop. Craven Arms, Shropshire, UK: Institute of Organic Training and Advice. http://orgprints.org/5582/ 1/Res_review_7_wright.doc. Accessed 5 March 2014

Wu T, Schoenau JJ, Li F, Qian P, Malhi SS, Shi Y (2003) Effect of tillage and rotation on organic carbon forms of chernozemic soils in Saskatchewan. Journal of Plant Nutrition and Soil Science 166: 328-335

Yau SK, Ryan J (2013) Differential impacts of climate variability on yields of rainfed barley and legumes in semi-arid Mediterranean conditions. Arch Agron Soil Sci 59:1659-1674. doi:10.1080/ 03650340.2013 .766322

Zentner RP, Wall DD, Nagy CN, Smith EG, Young DL, Miller PR, Campbell CA, McConkey BG, Brandt SA, Lafond GP, Johnston AM, Derksen DA (2002) Economics of crop diversification and soil tillage opportunities in the Canadian prairies. Agron J 94:216-230. doi:10.2134/agronj2002.2160

Zerhusen-Blecher P, Schäfer BC (2013) Stand des Wissens und Ableitung des Forschungsbedarfes für eine nachhaltige Produktion und Verwertung von Ackerbohne und Erbse. Fachhochschule Südwestfalen, Fachbereich Agrarwirtschaft Soest, Soest

Zilles P (2010) Futtererbsen, eine Anbaualternative zu Braugerste. Dienstleistungszentren Ländlicher Raum Rheinland-Pfalz, Bad Kreuznach, www.dlr.rlp.de/Internet/global/themen.nsf/ALL/ e d e e 880 a 3 a 786 e 65 c 125771100415795 ? OpenDocument\&ExpandSection=6. Accessed 5 March 2014

Zimmer S, Messmer M, Haase T, Piepho H-P, Mindermann A, Schulz H, Habekuß A, Ordon F, Wilbois K-P, Heß J (2016) Effects of soybean variety and Bradyrhizobium strains on yield, protein content and biological nitrogen fixation under cool growing conditions in Germany. European Journal of Agronomy 72:38-46. doi:10.1016/ j.eja.2015.09.008 